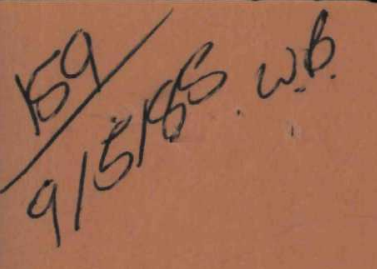

\title{
CLADDING CORROSION AND HYDRIDING IN IRRADIATED DEFECTED ZIRCALOY FUEL RODS
}

(LWBR Development Program)

J. C. CLAYTON

AUGUST 1985

DO NOT MICROFILM COVER

\section{CONTRACT NO. DE-AC11-76PN00014}




\section{DISCLAIMER}

This report was prepared as an account of work sponsored by an agency of the United States Government. Neither the United States Government nor any agency Thereof, nor any of their employees, makes any warranty, express or implied, or assumes any legal liability or responsibility for the accuracy, completeness, or usefulness of any information, apparatus, product, or process disclosed, or represents that its use would not infringe privately owned rights. Reference herein to any specific commercial product, process, or service by trade name, trademark, manufacturer, or otherwise does not necessarily constitute or imply its endorsement, recommendation, or favoring by the United States Government or any agency thereof. The views and opinions of authors expressed herein do not necessarily state or reflect those of the United States Government or any agency thereof. 


\section{DISCLAIMER}

Portions of this document may be illegible in electronic image products. Images are produced from the best available original document. 
(LWBR Development Program)

J.C. Clayton

August 1985
WAPD-TM--1393

DE85 017355

Contract No. DE-AC11-76PN00014

\author{
Printed in the United States of America \\ Available from the \\ National Technical Information Service \\ 5285 Port Royal Road \\ Springfield, Virginia 22161
}

\title{
NOTE
}

This document is an interim memorandum prepared for internal reference and does not represent a final expression of the opinion of Westinghouse. When this memorandum is distributed externally, it is with the express understanding that Westinghouse makes no representation as to completeness, accuracy, or usability of information contained herein.

BETTIS ATOMIC POWER LABORATORY

WEST MIFFLIN, PENNSYLVANIA 15122-0079

Operated for the U.S. Department of

Energy by WESTINGHOUSE ELECTRIC CORPORATION

WP: LWB82118N 


\title{
DISCLAIMER
}

\begin{abstract}
This report was prepared as an account of work sponsored by an agency of the United States Government. Neither the United States Government nor any agency thereof, nor any of their employees, makes any warranty, express or implied, or assumes any legal liability or responsibility for the accuracy, completeness, or usefulness of any information, apparatus, product, or process disclosed, or represents that its use would not infringe privately owned rights. Reference herein to any specific commercial product, process, or service by trade name, trademark, manufacturer, or otherwise does not necessarily constitute or imply its endorsement, recommendation, or favoring by the United States Government or any agency thereof. The views and opinions of authors expressed herein do not necessarily state or reflect those of the United States Government or any agency thereof.
\end{abstract}

\section{NOTICE}

This report was prepared as an account of work sponsored by the United States Government. Neither the United States, nor the United States Department of Energy, nor any of their employees, nor any of their contractors, subcontractors, or their employees, makes any warranty, express or implied, or assumes any legal liability or responsibility for the accuracy, completeness or usefulness of any information, apparatus, product or process disclosed, or represents that its use would not infringe privately owned rights. 


\section{FORENORD}

The Shippingport Atomic Power Station located in Shippingport, Pennsylvania was the first large-scale, central-station nuclear power plant in the United States and the first plant of such size in the world operated solely to produce electric power. This program was started in 1953 to confirm the practical application of nuclear power for large-scale electric power generation. It has provided much of the technology being used for design and operation of the cominercial, central-station nuclear power plants now in use.

Subsequent to development and successful operation of the Pressurized Water Reactor in the Atomic Energy Commission (now Department of Energy, DOE) owned reactor plant at the Shippingport Atomic Power Station, the Atomic Energy Commission in 1965 undertook a research and development program to design and build a Light Water Breeder Reactor core for operation in the Shippingport Station.

The objective of the Light Water Breeder Reactor (LWBR) program has been to develop a technology that would significantly improve the utilization of the nation's nuclear fuel resources employing the well-established water reactor technology. To achieve this objective, work has been directed toward analysis, design, component tests, and fabrication of a water-cooled, thorium oxideuranium oxide fuel cycle breeder reactor for installation and operation at the Shippingport Station. The LWBR core started operation in the Shippingport Station in the Fall of 1977 and finished routine power operation on October 1, 1982. The End-of-Life test program has been completed. The core has been removed and the spent fuel shipped to the Naval Reactors Expended Core Facility for detailed examination to verify core performance including an evaluation of breeding characteristics.

In 1976, with fabrication of the Shippingport LWBR core nearing completion, the Energy Research and Development Administration, now DOE, established the Advanced Water Breeder Applications (AWBA) program to develop and disseminate technical information which would assist U. S. industry in evaluating the LWBR concept for commerical-scale applications. The AWBA progran, which was concluded in September, 1982, explored some of the problems that would be faced by industry in adopting technology confirmed in the LWBR program. Information developed includes concepts for commercial-scale prebreeder cores which would produce uranium-233 for light water breeder cores while producing electric power, improvements for breeder cores based on the technology developed to fabricate and operate the Shippingport LWBR core, and other information and technology to aid in evaluating commercial-scale application of the LWBR concept.

All three development programs (Pressurized Water Reactor, Light Water Breeder Reactor, and Advanced Water Breeder Applications) have been conducted under the technical direction of the Office of the Deputy Assistant Secretary for Naval Reactors of DOE.

Technical information developed under the Shippingport, LWBR, and AWBA programs has been and will continue to be published in technical memoranda, one of which is this present report. 


\section{TABLE OF CONTENTS}

I. INTRODUCTION....................................... 1

A. The General Problem................................... 1

B. Purpose of Report.................................... 2

C. Defected Fuel Rod Corrosion and Hydriding................... 3

D. Background on the LWBR Fuel Rods........................ 4

II. LWBR DEFECTED FUEL ROD IRRADIATION TEST PROGRAM.............. 5

A. Experimental Details................................ 5

B. Post-Irradiation Examination Results..................... 7

1. Zircaloy-4 Cladding Corrosion....................... 7

2. Zircaloy -4 Cladding Hydriding......................... 9

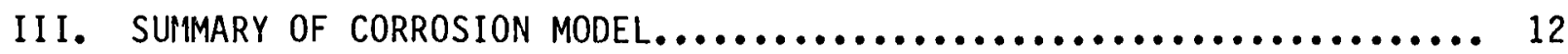

A. Model for Thermal Corrosion............................. 12

B. Analysis Model for Defected Fuel Rods....................... 13

C. Additional Corrosion at Inside Surface..................... 14

D. Calculational Details................................ 16

1. Cladding Temperature Calculation..................... 16

2. Calculational Assumptions.......................... 17

E. Comparison of Measurements With Calculations............... 18

1. Zircaloy -4 Cladding Corrosion.......................... 18

2. Zircaloy $-4 \mathrm{Cl}$ adding Hydriding......................... 19

IV. SUMMARY OF CORROSION AND HYDRIDING BEHAVIOR $\ldots \ldots \ldots \ldots \ldots \ldots \ldots \ldots \ldots \ldots$

V. CONCLUSIONS....................................... 23

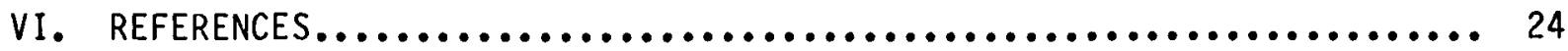

VII. ACKNOWLEDGEMENTS. .................................. 27

VIII. TABLES........................................... 28

IX. FIGURES. ........................................ 38

X. APPENDICES........................................ 44

A. CHORT Program Formulation............................. 44

B. LWBR Defected Rod Irradiation Test Program.................. 46

C. HYDIZ Analyses...................................... 48

D. List of Abbreviations and Acronyms....................... 54 


\section{LIST OF TABLES}

I. Irradiation Histories of LWBR Defected Test Rods with RXA Cladding...

II. Irradiation Histories of LWBR Defected Test Rods with SRA Cladding.................................. 29

III. Post-Irradiation Evaluation of LWBR Defected Test Rods........ 30

IV. Cladding Corrosion in LWBR Intentionally Defected Test Rods with RXA Zircaloy.......................................... 31

V. Cladding Corrosion in LWBR Defected Test Rods with SRA Zircaloy.......................................... 32

VI. Measured Hydrogen Distribution in LWBR Intentionally Defected Irradiation Test Rods......................... 33

VII. Measured and CHORT-Calculated Cladding Inside Surface Peak Power Corrosion of Intentionally Defected LWBR Irradiation Test Rods.

VIII. Measured and CHORT-Calculated Hydriding of Intentionally Defected LWBR Irradiation Test Rods.................... 37

A-I CHORT Input Constants for Zircaloy.................... 45

B-I LWBR Defected Irradiation Tests Containing Fuel Rods Examined for Cladding Corrosion and Hydriding................ 47

C-I Calculated Radial Hydrogen Diffusion in Rod 79-609D.......... 51

C-II Calculated Hydrogen Pickup and Axial Migration in Rod 79-6090......................................... 52

C-III Calculated Hydrogen Redistribution in Axial Segments of Rod 79-609D. 


\section{LIST OF FIGURES}

Figure

1

3

4

5

$C-1$
Title

Page

GRIP II IB Rod 79-6090 Defect Hole Streamer at Test Termination $(19,970 \mathrm{EFPH}) \ldots \ldots \ldots \ldots \ldots \ldots \ldots \ldots \ldots \ldots$

Hydrogen Gradients in GRIP IIIB Rod 79-6090................ 39

Accelerated and Massive Hydriding in GRIP IIIB Rod 79-6090.... 40

RXA Zircaloy Corrosion: Regression of Measured Versus CHORT-Calculated Outside 0xide Thickness................... 41

SRA Zircaloy-4 Corrosion: Regression of Measured Versus CHORT-Calculated Outside Oxide Thickness................. 42

Measured and CHORT-Calculated Inside Diameter Oxide Thickness of Intentionally Defected LWBR Irradiation Test Rods

GRIP-IIIB Rod 79-6090. 
Twenty-one LWBR irradiation test rods containing $\mathrm{ThO}_{2}-\mathrm{UO}_{2}$ fuel and Zircaloy cladding with holes or cracks operated successfully. Zircaloy cladding corrosion on the inside and outside diameter surfaces and hydrogen pickup in the cladding were measured. The observed outer surface Zircaioy cladding corrosion oxide thicknesses of the test rods were similar to thicknesses measured for nondefected irradiation test rods. An analysis model, which was developed to calculate outer surface oxide thickness of non-defected rods, gave results which were in reasonable agreement with the outer surface oxide thicknesses of defected rods. When the analysis procedure was modified to account for additional corrosion proportional to fission rate and to time, the calculated values agreed well with measured inner oxide corrosion film values. Hydrogen pickup in the defected rods was not directly proportional to local corrosion oxide weight gain as was the case for non-defected rods.

CLADDING CORROSION AND HYDRIDING IN IRRADIATED

DEFECTED ZIRCALOY FUEL RODS

(LWBR Development Program)

$$
\text { J. C. Clayton }
$$

I. INTRODUCTION

A. The General Problem

Nuclear power reactors are designed, manufactured, and operated to avoid conditions known to cause in-pile fuel rod cladding defects. Stringent controls on manufacturing and inspection minimize the probability of cladding fabrication defects. However, defected fuel rods (i.e., where the cladding has a through-thickness hole or crack) have occasionally occurred in both test reactors and commercial power reactors (References 1 through 3 ). In the event of a cladding defect, coolant can enter the rod interior and hence the cladding internal surface is subject to oxide corrosion and hydrogen pickup. Most defected Zircaloy fuel rods have operated satisfactorily until 
WAPD -TM-1393

removed during a normal refueling. However, under certain conditions Zircaloy cladding may be degraded over time and pose a threat to continued operation (References 1 through 3). Therefore, the operational behavior of defected fuel rods is an important engineering consideration for a reactor core.

\section{B. Purpose of Report}

This report, published as part of the Light Water Breeder (LWBR) Development Program, summarizes the cladding corrosion and hydriding results of the LWBR irradiation test program on defected $\mathrm{ThO}_{2}-\mathrm{UO}_{2}-$ fueled Zircaloy-4 clad rods. Two major consequences of defected rod operation, internal surface cladding corrosion and cladding hydrogen pickup, are examined to determine if defected fuel rod corrosion rates and hydrogen pickup behave similarly to those of non-defected Zircaloy-4 rods which are exposed to coolant on their outer diameter surfaces only. Cladding corrosion film thicknesses and hydrogen content measurements on intentionally defected Zircaloy-clad fuel rods from the LWBR irradiation test program are compared with values calculated by a computerized corrosion analysis procedure designated as CHORT (Corrosion and Hydriding of Reactor Tubing). The CHORT procedure was based on corrosion and hydriding data from non-defected irradiation test rods with only the outer cladding surface exposed to coolant. Predictions of corrosion oxide thicknesses are in reasonable agreement with measured data. However, hydrogen pickup in 
defected fuel rods was observed to behave differently than in nondefected rods. Unexpectedly high hydrogen concentration in cladding at low power segments of certain defected Zircaloy-4 fuel rods was observed and is attributed to gaseous hydrogen transport along the fuel rod cladding gap.

C. Defected Fuel Rod Corrosion and Hydriding

A defect is defined here as a breach of cladding integrity, i.e., a perforation, slit, or pinhole, that usually leaks fission products to the coolant and coolant to the rod internals.

A defected Zircaloy-clad fuel rod experiences greater cladding corrosion and hydriding than a normal non-defected rod since both inside and outside cladding surfaces are exposed to coolant. The amount of corrosion and hydriding on the outside surface of a defected fuel rod would be expected to be about the same as on a nondefected rod because cladding metallurgical condition and surface temperature are essentially unaffected by the defect. If a throughthickness defect occurs in the cladding, coolant can enter the fuel rod and reach high temperature when the core is taken to power. Corrosion and hydriding on the inside surface of the cladding will then occur at a faster rate than on the outside cladding surface due to higher temperatures at the inner surface and due to fissioning of fissile material on or very near the corroding surface. 
D. Background on the LWBR Fuel Rods

The Shippingport LWBR core contained 12 hexagonal-shaped modules which were arranged in a symmetric array surrounded by 15 reflector modules (Reference 4). Each of the hexagonal modules contained a central movable fuel assembly (seed) surrounded by a stationary blanket assembly. The fuel was in the form of ceramic pellets which were sealed within Zircaloy -4 tubes. In the seed and blanket regions, the fuel pellets were composed of the mixed oxides of uranium-233 and thorium-232 in solid solution. In the reflector region and in short sections at the tops and bottoms of the seed and blanket fuel rods, the pellets were $\mathrm{ThO}_{2}$. The seed-blanket-reflector configuration of the LWBR core had 17,287 fuel rods. LWBR fuel rod cladding was used in two metallurgical conditions, recrystallization annealed (RXA) seed rod tubing and stress-relief annealed (SRA) blanket and reflector rod tubing. Fuel rods were maintained in close-packed hexagonal arrays by AM-350 stainless steel grids. The LWBR core operated for 28,730 effective full power hours (EFPH)*. The absence of high coolant activity indicated that there were no fuel rod cladding defects.

太EFPH is the quotient of megawatt hours of operation and megawatt capability at $100 \%$ power. 
II. LWBR DEFECTED FUEL ROD IRRADIATION TEST PROGRAM

\section{A. Experimental Details}

Irradiation testing of defected fuel rods played an important role in development of fuel elements for the LWBR Core. The LWBR irradiation test program encompassed 30 individual tests of 271 fuel rods. The test rods were irradiated either in standard test reactor specimen holders or in bundles resembling portions of LWBR fuel rod modules (Reference 4). The coolant for these irradiation tests was pressurized water maintained at $\mathrm{pH} 10$ by $\mathrm{NH}_{4} \mathrm{OH}$ additions. Nineteen fuel rods (14 seed and 5 blanket) were intentionally defected with drilled holes (0.005-inch diameter) prior to testing. In addition, two blanket rods, which were irradiated at higher heat ratings than LWBR core rods, developed small cladding defects during planned inservice transient testing.

Al1 21 defected rods successfully operated with limited radioactivity release to the coolant. Startup activities, i.e., the values measured immediately after a defected test rod reached full power following a shutdown, were five to ten times greater than the steady state activities due to release of fission products to the coolant. These high activities declined over a period of one to three days to the steady state level. The steady state coolant activity values of irradiation tests with defected rods were higher than similar tests 
containing only non-defected rods. For example, the ${ }^{138} \mathrm{Cs}$ activity in the GRIP IIIA test with defected rod 79-6140 was $1 \times 10^{5} \mathrm{dpm} / \mathrm{ml}$ compared to an activity value of $5 \times 10^{4} \mathrm{dpm} / \mathrm{ml}$ for the GRIP IIIC test with no defected rods.

Irradiation histories of the 21 LWBR defected rods, including the two which defected in-pile, are given in Tables I and II for fuel rods with RXA and SRA cladding, respectively. The fuel rods with intentionally fabricated defects are identified by the letter "D" after the rod number. The seed-size irradiation test rods with RXA cladding (Table I) were irradiated to peak depletions up to $12 \times 10^{20}$ fissions/cc and peak fast neutron (>1 Mev) fluences up to $101 \times 10^{20}$ $\mathrm{n} / \mathrm{cm}^{2}$. The peak depletion and fluence for the LWBR core seed rods were $11 \times 10^{20}$ fissions $/ \mathrm{cc}$ and $97 \times 10^{20} \mathrm{n} / \mathrm{cm}^{2}$, respectively. The blanket-size test rods with SRA cladding (Table II) were irradiated to peak depletions up to $4 \times 10^{20}$ fissions/cc and fluences up to $12 \times$ $10^{20} \mathrm{n} / \mathrm{cm}^{2}$. The peak depletion and fluence for the LWBR core blanket rods were $5 \times 10^{20}$ fissions $/ \mathrm{cc}$ and $74 \times 10^{20} \mathrm{n} / \mathrm{cm}^{2}$.

LWBR irradiation tests pertinent to this corrosion and hydriding report are listed in Appendix B. Details of the destructive examination procedures for determining corrosion oxide film thickness and hydrogen contents of irradiated cladding samples are described in Reference (5). 


\section{B. Post-Irradiation Examination Results}

The post-irradiation evaluation tests performed on the 21 defected test fuel rods are listed in Table III. All of the defected rods were visually examined. Corrosion oxide thicknesses on the inside and outside cladding surfaces at or near the fuel rod peak power position were measured for 16 of the defected rods. The same 16 rods were analyzed for hydrogen content and distribution.

\section{Zircaloy -4 Cladding Corrosion}

Summaries of internal and external cladding corrosion data for the 16 LWBR irradiated defected test fuel rods that were destructively examined are presented in Tables IV and $V$ for RXA and SRA Zircaloy-4 cladding, respectively. External corrosion oxide thicknesses measured on the defected fuel rods were found to be about the same as those of non-defected rods with similar irradiation histories reported in Reference (5).

Nine of the intentionally fabricated defected rods showed a white or grey streak downstream from the defect hole. The defect hole streamer of GRIP II IB Rod 79-6090, shown in Figure 1, was observed at the first interim examination (1330 EFPH). At 2360 hours the streamer consisted of a bright white area and a darker 
phase extending downstream from the defect hole and increasing in width as the distance from the hole increased. With continued irradiation the white portion increased in area and covered the darker phase. Post-irradiation examination confirmed the streamer to be $\mathrm{ZrO}_{2}$. The nine oxide streamers were very local and had no noticeable effect on general cladding integrity. It is thought that either eroded $\mathrm{ThO}_{2}$ fuel or fission products emanating from the defect hole caused the accelerated corrosion of the Zircaloy cladding.

Internal cladding surface oxide films in the defected rods were usually more variable in thickness and several times thicker than the external oxide films. The thicker inner surface corrosion films are due to several factors: higher internal cladding surface temperatures (up to $780^{\circ} \mathrm{F}$ ), fission-induced corrosion acceleration at the internal surface (References 6 and 7), and exposure to a steam environment. The internal film on Rod 79587, however, was thinner than the external film because the rod was removed from test about 8.5 hours following the planned uppower transient test that produced the defect.

Four of the intentionally fabricated defected rods experienced cladding swelling. Rod 79-5040 swelled along the primary fuel stack. Three rods (79-4330, 79-3070, and 79-5830) had periods of normal dimensional changes during irradiation before any 
significant swelling, mainly in the plenum region, was detected. Blockage or partial blockage of the defect hole occurred in all four rods. The combination of hole blockage and swelling is indicative of waterlogging, $i . e$. , excessive internal pressure built up by trapped coolant which deforms the cladding.

\section{Zircaloy -4 Cladding Hydriding}

Measured hydrogen pickups in irradiated LWBR non-defected test rods and autoclaved Zircaloy-4 tubing specimens were proportional to measured outside diameter corrosion thickness (Reference 5 and 8). The hydriding in defected Zircaloy fuel rods falls into three categories: expected due to corrosion, accelerated, and massive.

Expected hydrogen pickup in defected rods results from the additional hydrogen which enters the cladding through the inside diameter $\mathrm{ZrO}_{2}$ film during corrosion. Twelve of the 16 destructively-examined defected LWBR test rods exhibited normal behavior of this type ( 100-1000 ppm hydrogen). Accelerated hydriding is defined as hydrogen absorption from the coolant far in excess of the nominal 25 percent pickup fraction of free $\mathrm{H}_{2}$ produced by the $\mathrm{Zr}-\mathrm{H}_{2} \mathrm{O}$ corrosion reaction for Zircaloy-4 ( several thousand ppm). Massive hydriding is the formation of regions of delta phase zirconium hydride in the cladding due to grossly accelerated hydrogen pickup $(16,300$ ppm). 
WAPD-TM-1393

The hydrogen contents of Zircaloy -4 cladding samples from the LWBR intentionally defected test rods are summarized in Table VI. Measurements were made with a vacuum extraction technique (Reference 5) and by visual comparison with known metallographic standards (Reference 9). Due to the greater internal surface corrosion, the total hydrogen contents in the defected rod cladding were several times those in non-defected rod cladding with similar irradiation histories. For example, in the GRIPIIIA test, defected rod 79-614D had $174 \mathrm{ppm}$ hydrogen in the peak power region, whereas companion non-defected rod 79-617 had only 40 ppm hydrogen (Reference 5).

Hydrogen pickup in non-defected fuel rods is proportional to corrosion oxide thickness and, therefore, is greater in peak power positions than in cooler, low power regions. In contrast, as shown in Table VI, several defected test rods 179-4330, 79-443D, 79-609D, and 79-614D), that were examined at several power positions, had higher hydrogen contents in cooler, low power cladding regions where the corrosion was less. Also, due to the steep temperature and higher hydrogen concentration radial gradients in defected rods, hydrogen tends to diffuse from the hotter inside cladding surface to the cooler outside surface; and this results in higher hydrogen concentrations at the outside cladding surface (Figure 2). All of the defected rods listed in Table VI had heavier hydride concentrations at their outside cladding surfaces. 
Several instances of localized accelerated and massive hydriding were observed (Figure 3). Two intentionally fabricated defected fuel rods (GRIP-II rod 79-443D and GRIP-IIIB rod 79-609D) had areas of accelerated hydriding with several thousand ppm of hydrogen. Localized areas of massive hydriding were found in C7-B3A rod 79-353, GRIP-II rod 79 441D, and GRIP-IIIB rod 796090. These localized areas were converted to solid zirconium delta hydride (approximately 16,300 ppm of hydrogen). Massive hydriding was also accompanied by dimensional changes in these three rods due to the lower density of zirconium delta hydride compared with Zircaloy-4. However, none of these incidents interfered with the operation of the irradiation tests. For example, C7-B3A rod 79-353, which defected in-pile due to iodine stress-corrosion cracking, operated successfully for about 12,000 EFPH even though during post-irradiation examination the cladding was observed to be massively hydrided near the bottom end of the rod. None of these hydrided rods lost additional structural integrity during operation which attests to their ability to function under localized accelerated and massive hydriding conditions. 
III. SUMMARY OF CORROSION MODEL

\section{A. Model for Thermal Corrosion}

Several theories have been advanced to explain the Zircaloy corrosion transition phenomenon. The cyclic transition theory (References 8, 10, and 11) postulates that at transition a fundamental change in the character of the Zircaloy corrosion oxide film allows repeated cyclic transitions of the oxide at a given thickness, thereby resulting in repeated reversions to the cubic kinetics of the beginning of the corrosion process. The CHORT analysis procedure and related computer program are based on the cyclic transition theory and are described in detail in Reference (8). The unique feature of the program is its representation of post-transition corrosion kinetics by repeated iterations of the pre-transition behavior. This cyclic behavior of the model represents a corrosion process in which the entire oxide film cracks or buckles, thereby allowing permeation of oxidant directly from the environment and resulting in a restart of the original corrosion rate. A stress-diffusion model has been proposed in References (10) and (12) to explain the change in kinetics.

Both out-of-pile and in-pile test data indicate that stress-relief annealed (SRA) Zircaloy-4 corrodes considerably faster than recrystallization annealed (RXA) Zircaloy-4 tubing (Reference 5 and 8). The differences in corrosion behavior were weight gain at 
transition (lower for SRA) and post-transition rate (higher for SRA). Prior to transition, both materials behaved the same.

The CHORT analysis procedure accomodates these observed differences between SRA and RXA tubing. It is assumed in the procedure that the difference in material weight gain can be attributed to a difference in the periodicity of a postulated cyclic transition of the oxide. A correction for the effect of radiation is also included in the procedure (Reference 5).

B. Analysis Model for Defected Fuel Rods

Since the environment at the inside cladding surface of a defected fuel rod is more corrosive than that on the outside surface, the computer program was modified by the addition of a corrosion enhancement term, discussed in detail in Section III $C$, to model the effect of fission activity on or near the cladding surface. Since surface fissioning enhancement effects are assumed to be caused by fission product recoil, the enhancement effect should be linear with respect to time and directly proportional to the fissioning rate, i.e.,

$$
W_{S F}=k \dot{f} t,
$$

where

$$
W_{S F}=\begin{aligned}
& \text { corrosion weight gain/unit area due to fission fragment } \\
& \text { damage, }
\end{aligned}
$$




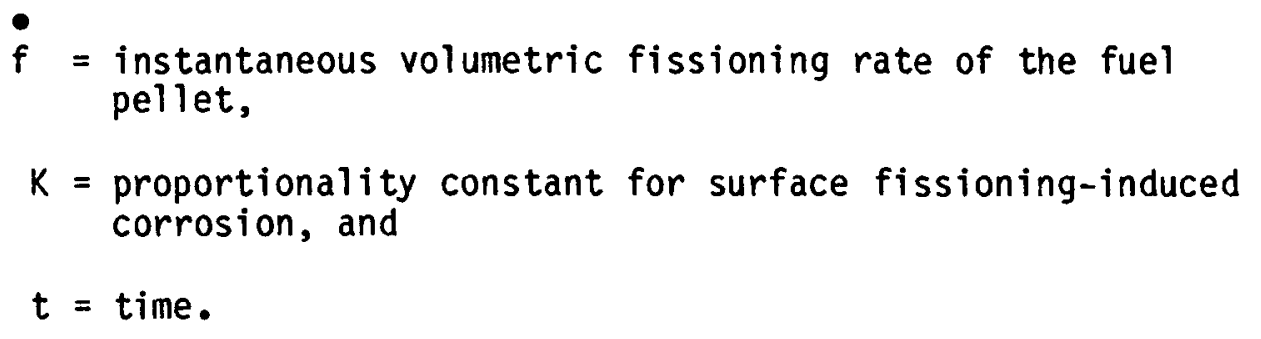

Total weight gain is obtained by adding thermal weight gain $\left(W_{T H}\right)$, irradiation-induced weight gain $\left(W_{R A D}\right)$, and surface fissioninginduced weight gain, i.e.,

$$
W_{T O T}=W_{T H}+W_{R A D}+W_{S F} \cdot
$$

The method of solution employed in CHORT is to solve Equation (2) for any given time step, $\Delta t$. When the total calculated weight gain reaches the transition value specified in the input, the equation is repeated for another cycle. This cyclic transition represents corrosion behavior in which the entire oxide filn cracks or buckles, thereby allowing penetration of oxidant directly to the metal surface. The CHORT program formulation is described in Appendix A.

C. Additional Corrosion at Inside Surfaces

The surface fissioning-induced weight gain term in the weight gain calculation, Equation (2), has been correlated with measured corrosion enhancement on the inside surfaces of defected LWBR irradiation test rods. As evidence for this effect, the corrosion enhancement which occurred downstream of the defect hole on the 
external rod surface ("streamer") can be cited. The effect is attributed to fissioning of fissile material on or very near the corroding surface.

The modeling of accelerated Zircaloy corrosion due to surface fissioning has been reported by Cox (Reference 6) and Jenks (Reference 7). Increased inner cladding surface corrosion has been historically attributed to the effects of surface fissioning enhancement covered by the proximity of the fuel pellets (References 6 and 7). Both Cox and Jenks achieved some modeling success by applying an acceleration factor or adding an additional term to the corrosion rate equation. The acceleration effect developed for CHORT is equivalent to the Jenks' calculation using a low power factor (about 1 watt $/ \mathrm{cm}^{3}$ ) surface damage term but is linear and not quadratic (as proposed by Jenks) with fissioning rate. Use of a quadratic term did not significantly improve the fit between the model and the observed corrosion measurements. Surface fissioning rates in the LWBR irradiation test rods covered a much narrower range than Jenks' values. Surface fissioning rate is assumed directly proportional to volumetric fissioning rate. 
D. Calculational Details

1. Cladding Temperature Calculation

In order to calculate the contribution of thermal (temperature activated) corrosion to the oxide film growing on the inside fuel rod surface, an estimate of temperature is necessary. A best estimate calculation of the inside cladding surface temperature was obtained with the Fission Irradiation Growth (FIGRO) analysis procedure, Reference 13. For each defected fuel rod analyzed, a detailed history was constructed for each cycle of irradiation (approximately 500 hours); this included cycle average values of heat flux, fast neutron flux ( $>1 \mathrm{MeV})$, coolant temperature, and system pressure.

The FIGRO calculation was performed at the axial position of the oxide film measurement; it provided a calculated inside cladding surface temperature and fissioning rate for each cycle of irradiation. For this calculation, effects on temperature of the growing oxide corrosion layers were ignored since the effect is zero at the inner cladding surface corroding interface and small (about $10^{\circ} \mathrm{F}$ for the highest heat flux position) at the outer surface. 


\section{Calculational Assumptions}

The following assumptions were made in performing the calculation for defected rods:

a. The weight gain to transition, $W_{T R}$, remains unaffected by the presence or absence of a defect in the rod. In the model RXA Zircaloy cladding has a higher transition weight gain, 31.00 $\mathrm{mg} / \mathrm{dm}^{2}$, than SRA material, $27.53 \mathrm{mg} / \mathrm{dm}^{2}$, (References 5 and $6)$. Thus, in defected fuel rods with the same irradiation environment, SRA Zircaloy would exhibit a higher corrosion weight gain than RXA material.

b. The time at temperature was approximated by the relationship:

$$
0.9 t=E F P H,
$$

where

$$
t=\text { time at temperature in hours, and }
$$

$E F P H=$ effective full power hours.

c. In order to determine the value of the proportionality constant for surface fissioning, $K$, of equation (1), a series of parametric CHORT calculations was performed for each of eight destructively examined, defected fuel rod modeled. Values of $K$ were chosen to produce a least-squares fit between CHORT-calculated and observed oxide thicknesses. 
With this technique, it was found that the minimum in the root mean square errors occurs at a $K$ value arcund $2.0 \times$ $10^{-19}$.

\section{E. Comparison of Measurements With Calculations}

1. Zircaloy -4 Cladding Corrosion

The CHORT computer program was developed to predict the corrosion performance of LWBR non-defected fuel rod cladding. The model successfully predicted outer surface corrosion and hydrogen pickup for non-defected irradiated Zircaloy-4 tubing specimens (References 5 and 8 ). The next step was to determine if the external surface cladding corrosion of defected fuel rods could be determined by a model based on non-defected rods. The external cladding thickness measurements for the 16 LWBR intentionally defected irradiated test rods that were destructively examined are compared with calculated values in Tables IV and $V$ for RXA and SRA Zircaloy-4 cladding respectively. The data show that the calculated thicknesses are in agreement with experimental measurements. The external oxide thickness data for defected and non-defected LWBR test rods are compared in Figures 4 and 5. In general, both defected and nondefected test rods with similar irradiation histories had similar oxide corrosion film thicknesses and were in reasonable agreement with the model calculations. 
The model was then modified to account for additional corrosion enhancement caused by fission product recoil on the cladding inner surface, and measured internal corrosion oxide film thicknesses were compared with predicted values. A comparison of the measured inside diameter corrosion oxide thickness with calculated values for eight intentionally fabricated defected test rods, for which detailed irradiation histories were available, is given in Table VII and plotted in Figure 6 . The data show that the measured thicknesses are accurately predicted by the modified procedure. These results indicate that, except for the additive effect of fissile surface enhancement, corrosion rates at the cladding inside surface are proportional to the inside surface temperature in a similar manner to corrosion at the cladding outside surface of both non-defected and defected rods.

2. Zircaloy -4 Cladding Hydriding

The CHORT model for calculating hydrogen absorption in Zircaloy is based on the performance of non-defected irradiation test rods where hydrogen pickup is proportional to corrosion oxide thickness. Although this relationship between oxide thickness and hydrogen content is most often not the case for defected rods, hydrogen pickup values were calculated for illustrative comparison purposes. 
The initial hydrogen contents of the test rod claddings were 10 to $14 \mathrm{ppm}$. Hydrogen uptake measurements were calculated from the predicted corrosion oxide thicknesses using Equation (4):

$\Delta H \mathrm{ppm}=\frac{(11.8987 \Delta \mathrm{T}-0.1824)(0.6 \mathrm{~N})}{t}$,

where

$\Delta H \mathrm{ppm}=$ hydrogen pickup in ppm,

$\Delta T=$ corrosion oxide thickness in mils,

$N=$ number of corroding surfaces, and

$t=$ rod cladding thickness in inches.

Measured and calculated hydrogen concentrations of the eight defected LWBR test rods described in Table VII are compared in Table VIII. The hydrogen contents at and near the high power levels $(90-100 \%)$ can be combined into two groups. The hydrogen concentrations in the four defected rods with lower irradiation times ( $\leq 3690 \mathrm{EFPH})$ and thinner inner oxide films $(\leq 1 \mathrm{mil})$ are similar in behavior to non-defected rods in that hydrogen pickup is proportional to corrosion thickness. For the four defected rods with longer irradiation times (5900-19,970 EFPH) and thicker inner oxide films $(\sim 1-2.0 \mathrm{mils})$, the measured hydrogen values are appreciably less than would be expected based on the assumption that hydrogen pickup is proportional to corrosion 
thickness. Finally, the accelerated hydriding observed at the $5 \%$ power position of rod 79-609D is greatly underpredicted since the oxide thickness at that location is small. Thus, hydrogen pickup in defected rods is for the most part not proportional to oxide thickness. An alternate mechanism must be considered.

Axial diffusion of hydrogen within the Zircaloy cladding to cooler regions of a fuel rod would provide a ready and simple explanation for the data of Table VIII. However, for significant axial diffusion to occur, it would be necessary for the longitudinal temperature gradient to be a controlling gradient, i.e., it must be significantly large with respect to either the radial or circumferential gradient (Reference 14). This is not the case in defected LWBR irradiation test rods, and analyses with the HYDIZ (Hydrogen Distribution in Zircaloy) hydrogen diffusion computer program (Reference 15) predicted very little hydrogen diffusion in the cladding in the axial direction. The results of the HYDIZ analyses are discussed in Appendix C. In addition, when intentionally defected Zircaloy-clad fuel rods containing $\mathrm{UO}_{2}$ were isothermally corrosion tested out-of-reactor in a steam-hydrogen atmosphere, accelerated hydriding of the Zircaloy was consistently observed in rod regions at a considerable distance away from the defect hole (Reference 16). These results suggest that hydrogen is transported by diffusion to end regions of rods in the gaseous state via the fuel-cladding gap and is thus absorbed preferentially in these regions. 
Hydrogen transport through the fuel-cladding gap can also occur in irradiated defected fuel rods by the following sequence of events. First coolant enters the rod through the defect and oxidizes the inner Zircaloy cladding surface through the reaction $\mathrm{Zr}+2 \mathrm{H}_{2} \mathrm{O}+\mathrm{ZrO}_{2}+2 \mathrm{H}_{2}$. The hydrogen that is not absorbed by the Zircaloy (about $75 \%$ ) is released to the fuel-cladding gap, thus enriching the atmosphere in hydrogen. In addition, some of the coolant entering the defect is decomposed to hydrogen and peroxide by radiolysis, $2 \mathrm{H}_{2} \mathrm{O} \rightarrow \mathrm{H}_{2} \mathrm{O}_{2}+\mathrm{H}_{2}$. Thus the oxidant partial pressure is reduced both by corrosion of the internal surface of the Zircaloy cladding and by peroxide oxidation of the fuel. High levels of free hydrogen generated by the radiolysis of the coolant and fuel and cladding oxidation can migrate through the fuel cladding gap to the end regions of the defected rod where the hydrogen is absorbed.

IV. SUMMARY OF CORROSION AND HYORIDING BEHAVIOR

A. Oxide films on internal surfaces of defected Zircaloy-4 fuel rods were several times as thick as films on external surfaces. This can be explained both by higher temperatures at the internal surface and by the effect of surface fissile enhancement.

B. Total hydrogen contents in defected fuel rod cladding were several times those in non-defected rod cladding. Further, evidence of 
hydrogen migration to cooler regions of the rods remote from the defect hole was observed, indicating that hydrogen pickup is not proportional to corrosion oxide thickness.

C. Hydrogen levels in the cladding of the defected fuel rods were generally higher at the external surface than at the internal surface because, in a sufficiently high thermal gradient, hydrogen diffuses toward the cooler region.

D. Defected rods with areas of accelerated or massive hydride continued to operate satisfactorily.

\section{CONCLUSIONS}

A. The measured outer surface Zircaloy cladding corrosion oxide thicknesses of both defected and non-defected LWBR irradiation test rods were similar and can be calculated using a model based on nondefected outer surface corrosion experience.

B. There is a significant corrosion enhancement on the inside cladding surface in defected Zircaloy fuel rods which can be attributed to radiation damage caused by fission product recoil from the fissioning fuel. 
C. When modified to account for the additional corrosion caused by fission activity on the inner Zircaloy cladding surface, a model qualified to the corrosion of non-defected rods provided calculated values which agree well with measured inner oxide corrosion film values.

D. Hydrogen concentrations are higher than predicted in the lower power segments of defected Zircaloy fuel rods and are not proportional to oxide thicknesses. This phenomenon is attributed to gaseous hydrogen transport through the fuel-cladding gap and results in high hydrogen concentrations in the gap at the top and bottom ends of the defected rod.

E. Hydrogen absorption models in which hydrogen pickup is calculated to be directly proportional to local corrosion oxide weight gain, while adequate for the prediction of external hydriding in non-defected rods, are unsuitable for prediction of axial hydrogen distribution in defected Zircaloy rods.

\section{REFERENCES}

1. D. H. Locke, "Defected Zircaloy Fuel," Nucl. Eng. Int., 14, 648-652 (1969). 
2. D. H. Locke, "Review of Experience with Water Reactor Fuels 1968-1973, Nucl. Eng. Des., 33, 94-124 (1975).

3. D. H. Locke, "The Behavior of Defective Reactor Fuel," Nucl. Eng. Des., 21, 319-330 (1972).

4. D. R. Connors, S. Mi lani, J. A. Fest, and R. Atherton, "Design of the Shippingport Light Water Breeder Reactor," WAPO-TM-1208 (January 1979).

5. J. C. Clayton, "Corrosion and Hydriding of Irradiated Zircaloy Fuel Rod Cladding," WAPD-TM-1440 (September 1982).

6. B. Cox, K. Alcock, and F. W. Derrick, "The Oxidation and Corrosion of Zirconium and its Alloys. VI. The Mechanism of Fission Fragment, Induced Corrosion of Zi rcaloy-2," J. Electrochem. Soc., 108, 129-133 (1961).

7. G. H. Jenks, "Zi rcaloy-2 Corrosion In-Pile in Aqueous Homogeneous, Reactor Solutions," in "Corrosion of Zirconi um Alloys," ASTM STP 368, American Society for Testing and Materials, 1964, pp. 41-57.

8. G. P. Marino and R. L. Fischer, "Corrosion of Zircaloy-4 Tubing in $680^{\circ}$ Water," WAPD-TM-1322 (December 1978). 
9. B. Z. Hyatt, "Metallographic Standards for Estimating Hydrogen Content of Zircaloy-4 Tubing," WAPD-TM-1431 (February 1982).

10. J. S. Bryner, "The Cyclic Nature of Corrosion of Zircaloy-4 in $633 \mathrm{~K}$ Water," J. Nuc1. Mater., 82, 84-101 (1979).

11. H. R. Peters, "Improved Characterization of Aqueous Corrosion Kinetics of Zircaloy-4," in "Zirconium in the Nuclear Industry," ASTM STP 824, American Society for Testing and Materials, 1984, pp. 507-518.

12. C. C. Dollins and M. Jursich, "A Model for the Oxidation of Zirconi um-Base Alloys," WAPD-TM-1495 (May 1981).

13. I. Goldberg, "A Procedure for Calculations of Steady-State Temperature in Zircaloy-Clad, Bulk Oxide Fuel Elements Using the FIGRO Computer Program," WAPD-TM-757 (November 1969).

14. D. W. Shannon and R. E. Westerman, "Hydriding and Thermal Redistribution of Hydrogen in N-Reactor Zircaloy Process Tubes," HW77602 RD, May 28, 1963.

15. G. P. Marino, "HYDIZ-A Two-Dimensional Computer Program for Migration of Interstitial Solutes of Finite Solubility in a Thermal Gradient," WAPD-TM-1157 (June 1974). 
16. R. F. Boyle and T. J. Kisiel, "Hydrogen Permeation of Zircaloy-2 Corrosion Films," Bettis Technical Review, WAPD-BT-10, 31-48 (1958).

\section{ACKNOWLEDGEMENTS}

Many persons at the Bettis Laboratory contributed to the work upon which this report is based. T. H. Alff, J. T. Engel, R. C. Hoffman, L. R. Lynam, D. A. Mertz, J. Sherman, C. D. Sphar, and Dr. L. A. Waldman directed the LWBR irradiation tests, M. J. Shawley assisted in programming, and Dr. P. L. Pfennigwerth provided program management and support. Particularly significant is the work of D. M. Ivak who modified the CHORT computer program to include inner cladding surface corrosion and provided considerable written material for this report. T. H. Alff, B. M. Berquist, E. Duncombe, W. E. Franzen, R. A. Frederickson, I. Goldberg, E. Hillner, E. A. McCabe, P. L. Pfennigwerth, J. V. Reining, and H. R. Warner reviewed the report. 
TABLE I

Irradiation Histories of LWBR Defected Test Rods With RXA Cladding

\begin{tabular}{|c|c|c|c|c|c|}
\hline Test & $\operatorname{Rod} \star \star$ & $\begin{array}{l}\text { Irradiation } \\
\text { Time } \\
\text { (EFPH) }\end{array}$ & $\begin{array}{c}\text { Peak } \\
\text { Pepletion } \\
\left(10^{2} \text { fissions } / c c\right)\end{array}$ & $\begin{array}{c}\text { Peak } \\
\text { F) pence } \\
\left(10^{20 \text { n/cm }}{ }^{2}\right)\end{array}$ & $\begin{array}{l}\text { Time-Averaged } \\
\text { Fast Neutron Flux } \\
\left(10^{14} \mathrm{n} / \mathrm{cm}^{2}-\mathrm{sec}\right)\end{array}$ \\
\hline$M-13-S 2$ & $\begin{array}{l}79-3210 \\
79-3220\end{array}$ & $\begin{array}{l}2120 \\
2120\end{array}$ & $\begin{array}{l}1.9 \\
1.9\end{array}$ & $\begin{array}{l}11.3 \\
11.3\end{array}$ & $\begin{array}{l}1.48 \\
1.48\end{array}$ \\
\hline$M-13-S 3$ & $79-3310$ & 7670 & 8.7 & 16.0 & 0.58 \\
\hline$M-13-S 3 A$ & $79-4840$ & 11,020 & 11.7 & 34.1 & 0.86 \\
\hline$M-13-S 4$ & $\begin{array}{l}79-5940 \\
79-5950\end{array}$ & $\begin{array}{l}5975 \\
1235\end{array}$ & $\begin{array}{l}5.0 \\
1.3\end{array}$ & $\begin{array}{c}23.3 \\
5.8\end{array}$ & $\begin{array}{l}1.08 \\
1.30\end{array}$ \\
\hline GRIP-II & $\begin{array}{l}79-4410 \\
79-4430\end{array}$ & $\begin{array}{l}4850 \\
3690\end{array}$ & $\begin{array}{l}5.2 \\
4.9\end{array}$ & $\begin{array}{l}35.0 \\
23.5\end{array}$ & $\begin{array}{l}2.00 \\
1.77\end{array}$ \\
\hline GRIP-IIIA & $79-6140$ & 5900 & 4.6 & 31.0 & 1.46 \\
\hline GRIP-IIIB & $79-6090$ & 19,970 & 9.7 & 98.0 & 1.36 \\
\hline LSR & $79-4330$ & 7240 & 7.1 & 3.5 & 0.13 \\
\hline $\begin{array}{l}\text { Production } \\
\text { Thoria }\end{array}$ & $\begin{array}{l}81-820 \\
81-840\end{array}$ & $\begin{array}{l}2545 \\
2545\end{array}$ & $\begin{array}{l}0.2 \\
0.2\end{array}$ & $\begin{array}{l}9.0 \\
9.0\end{array}$ & $\begin{array}{l}0.98 \\
0.98\end{array}$ \\
\hline
\end{tabular}

* All rods intentionally defected with 0.005 -inch drilled hole during fabrication ** Seed-diameter rods 
Table II

Irradiation Histories of LWBR Defected Test Rods With SRA Cladding

\begin{tabular}{|c|c|c|c|c|c|}
\hline Test & Rod* & $\begin{array}{c}\text { Irradiation } \\
\text { Time } \\
\text { (EFPH) }\end{array}$ & $\begin{array}{c}\text { Peak } \\
\text { Depletion } \\
\left(10^{20} \text { fissions } / c c\right)\end{array}$ & $\begin{array}{c}\text { Peak } \\
\text { Fluence } \\
\left(10^{\left.20^{2} / \mathrm{cm}^{2}\right)}\right.\end{array}$ & $\begin{array}{l}\text { Time-Averaged } \\
\text { Fast Neutron Flux } \\
\left(10^{1} \mathrm{n} / \mathrm{cm}^{2}-\mathrm{sec}\right)\end{array}$ \\
\hline$C 7-B 3$ & 79-301D & 2160 & 0.3 & 2.3 & 0.30 \\
\hline \multirow[t]{2}{*}{$C 7-B 3 A$} & $79-3070$ & 10,510 & 2.1 & 11.0 & 0.29 \\
\hline & $79-353+$ & 11,950 & 2.8 & 12.2 & 0.28 \\
\hline $\mathrm{C} 7-\mathrm{BBT}$ & $79-504 D$ & 12,080 & 3.6 & 10.4 & 0.24 \\
\hline SBR & $79-5500$ & 1490 & 0.5 & 0.4 & 0.07 \\
\hline \multirow[t]{2}{*}{ NLBR } & $79-5830$ & 4820 & 1.8 & 1.9 & 0.11 \\
\hline & $79-587+$ & 7760 & 2.3 & 2.3 & 0.08 \\
\hline $\begin{array}{l}\text { Production } \\
\text { Thoria }\end{array}$ & $81-890 * \star$ & 2545 & 0.2 & 9.0 & 0.98 \\
\hline
\end{tabular}

+ Defected in-service; all others intentionally defected with 0.005 -inch drilled hole during fabrication

* Blanket-diameter rods except for $82-890$

** Seed-di ameter rod 
Table III

\begin{tabular}{|c|c|}
\hline Test & Rod \\
\hline $1-13-52$ & $\begin{array}{l}79-3210 \\
79-322 D\end{array}$ \\
\hline$-13-53$ & $79-3310$ \\
\hline $1-13-53 A$ & $79-484 D$ \\
\hline$-13-54$ & $\begin{array}{l}79-594 D \\
79-5950\end{array}$ \\
\hline RIP-II & $\begin{array}{l}79-4410 \\
79-4430\end{array}$ \\
\hline RIP-IIIA & $79-614 D$ \\
\hline RIP-I I IB & $79-6090$ \\
\hline$S R$ & $79-4330$ \\
\hline $\begin{array}{l}\text { roduction } \\
\text { horia }\end{array}$ & $\begin{array}{l}81-82 D \\
81-84 D \\
81-89 D\end{array}$ \\
\hline 7-B3 & $79-3010$ \\
\hline $7-B 3 A$ & $\begin{array}{l}79-307 D \\
79-353\end{array}$ \\
\hline 7 BBT & $79-5040$ \\
\hline$B R$ & $79-5500$ \\
\hline LBR & $\begin{array}{l}79-583 D \\
79-587\end{array}$ \\
\hline
\end{tabular}

Post-Irradiation Evaluation of LWBR Defected Test Rods

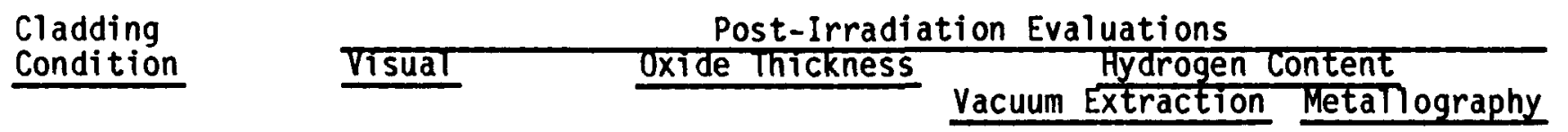

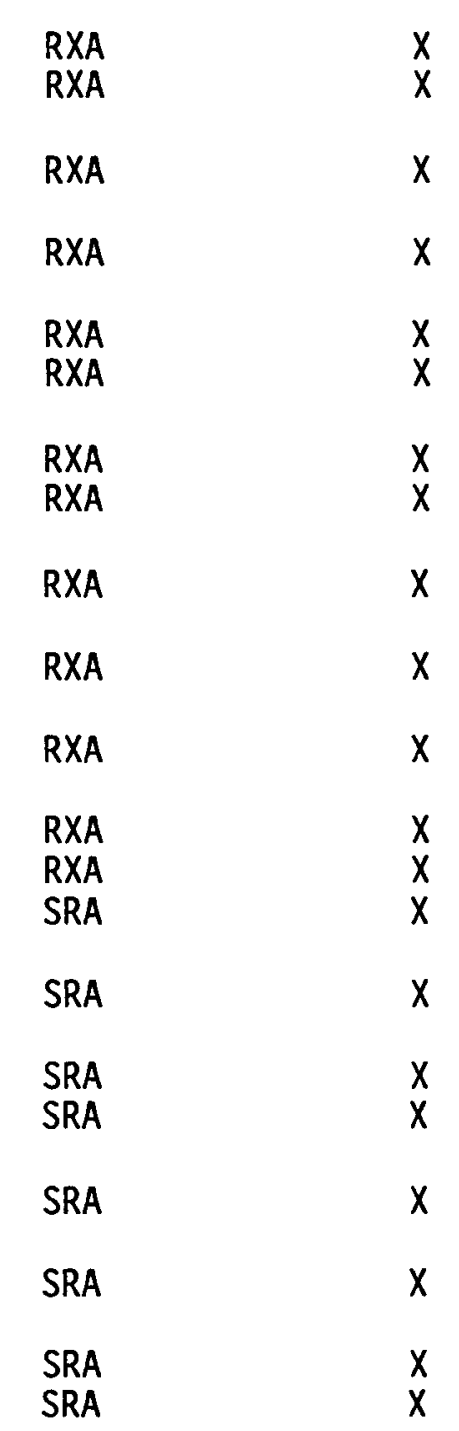


Table IV

Cladding Corrosion in LWBR Intentionally Defected Test Rods With RXA Zircaloy

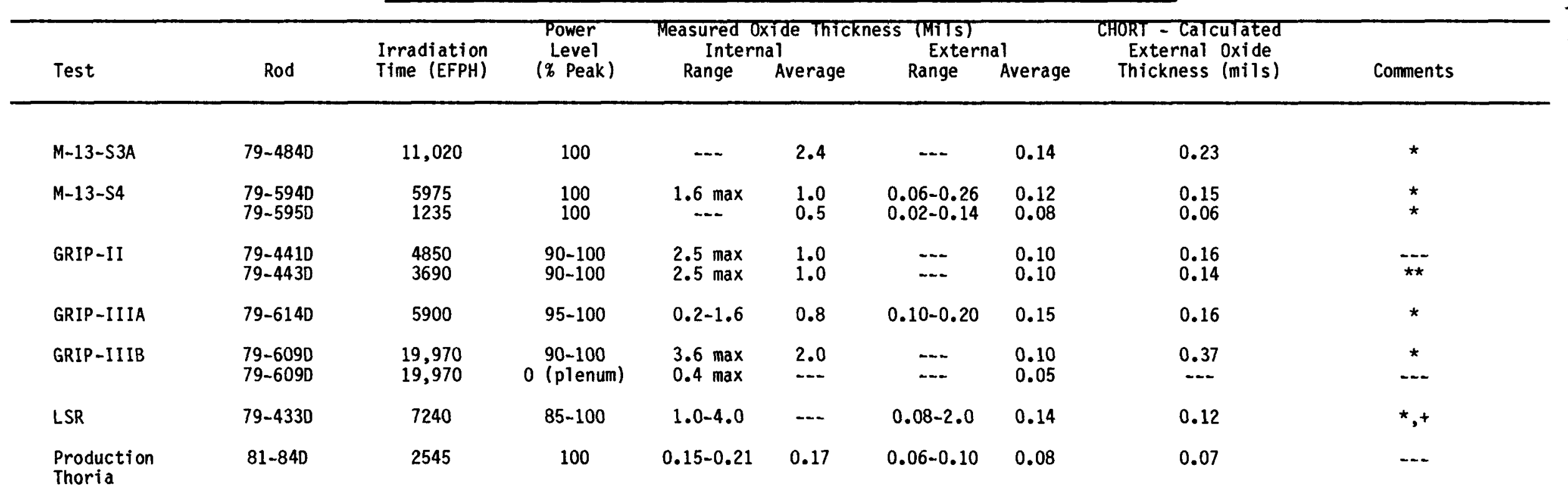

* Flow pattern downstream of defect hole

** Rod 79-4430 touched an adjacent rod during all or part of $i$ ts irradiation

+ Defect hole plugged; rod swelled in plenum region 
Table V

Cladding Corrosion in LWBR Defected Test Rods With SRA Zircaloy

\begin{tabular}{|c|c|c|c|c|c|c|c|c|c|}
\hline Test & Rod & $\begin{array}{l}\text { Irradiation } \\
\text { Time (EFPH) }\end{array}$ & $\begin{array}{c}\text { Power } \\
\text { Level } \\
\text { (\% Peak) }\end{array}$ & $\begin{array}{l}\text { Measured } \\
\text { Intern } \\
\text { Range }\end{array}$ & $\begin{array}{l}\text { oxide Thic } \\
\text { la) } \\
\text { Average }\end{array}$ & $\begin{array}{c}\text { iess (mits) } \\
\text { Extern } \\
\text { Range }\end{array}$ & Average & $\begin{array}{l}\text { CHORT - Calculated } \\
\text { External Oxide } \\
\text { Thickness (mils) }\end{array}$ & Comments \\
\hline$C 7-B 3 A$ & $\begin{array}{l}79-307 D \\
79-353\end{array}$ & $\begin{array}{l}10,510 \\
11,950\end{array}$ & $\begin{array}{c}80-100 \\
98\end{array}$ & $\begin{array}{l}0.5-1.20 \\
0.34-0.60\end{array}$ & $\begin{array}{l}0.8 \\
0.46\end{array}$ & $\begin{array}{l}0.10-0.20 \\
0.19-0.31\end{array}$ & $\begin{array}{l}0.15 \\
0.23\end{array}$ & $\begin{array}{l}0.16 \\
0.26\end{array}$ & $\stackrel{+}{\star}$ \\
\hline C7-BBT & $79-5040$ & 12,080 & $92-95$ & $1.5 \max$ & 1.04 & $0.07-0.24$ & 0.18 & 0.21 & + \\
\hline SBR & $79-5500$ & 1490 & 100 & $0.20-0.40$ & $\cdots$ & $\cdots$ & 0.04 & 0.05 & $\star \star$ \\
\hline NLBR & $\begin{array}{l}79-5830 \\
79-587\end{array}$ & $\begin{array}{l}4820 \\
7760\end{array}$ & $\begin{array}{l}100 \\
100\end{array}$ & $\begin{array}{l}0.05-0.40 \\
0.02-0.12\end{array}$ & 0.07 & $\begin{array}{l}0.05-0.08 \\
0.12-0.16\end{array}$ & $\begin{array}{l}0.07 \\
0.15\end{array}$ & $\begin{array}{l}0.06 \\
0.10\end{array}$ & $\star \star *,++$ \\
\hline $\begin{array}{l}\text { Production } \\
\text { Thoria }\end{array}$ & $81-890$ & 2545 & 100 & $0.15-0.21$ & 0.18 & $0.06-0.10$ & 0.08 & 0.07 & $\cdots$ \\
\hline
\end{tabular}

* Defected in-pile

* Flow pattern downstream of defect hole

+ Defect hole plugged; rod swelled

++ Defect hole partially open; rod swelled in plenum region 
Table VI

Measured Hydrogen Distribution in LWBR Intentionally Defected Irradiation Test Rods

\begin{tabular}{|c|c|c|c|c|}
\hline Rod & $\begin{array}{l}\text { Irradiation } \\
\text { Time (EFPH) }\end{array}$ & $\begin{array}{l}\text { Power } \\
\text { Level } \\
(\% \text { Peak })\end{array}$ & $\begin{array}{l}\text { Measured Hy } \\
\text { Vacuum } \\
\text { Extraction }\end{array}$ & $\begin{array}{l}\text { en Content (ppm) } \\
\text { Metallography }\end{array}$ \\
\hline 79-307D & 10,510 & $\begin{array}{r}100 \\
93 \\
80\end{array}$ & $\begin{array}{l}151 \\
328 \\
160\end{array}$ & $\begin{array}{l}100 \mathrm{ppm} \text { at inner surface, } \\
300 \mathrm{ppm} \text { at outer surface (away from defect hole); } \\
100-150 \mathrm{ppm} \text { near defect hole. }\end{array}$ \\
\hline $79-4330$ & 7240 & $\begin{array}{c}100 \\
\star \\
85\end{array}$ & $\begin{array}{l}382 \\
265 \\
542\end{array}$ & $\begin{array}{l}75-100 \mathrm{ppm} \text { in inner } 2 / 3 \text { of cladding, } \\
300-600 \mathrm{ppm} \text { in outer } 1 / 3 \text { of cladding; } \\
225 \mathrm{ppm} \text { near defect hole }\end{array}$ \\
\hline $79-4410$ & 4850 & 100 & 270 & $\begin{array}{l}75-100 \mathrm{ppm} \text { at inner surface; } 400-600 \mathrm{ppm} \text { at } \\
\text { outer surface }\end{array}$ \\
\hline $79-4430$ & 3690 & $\begin{array}{r}100 \\
93 \\
90\end{array}$ & $\begin{array}{l}365 \\
505 \\
403\end{array}$ & $\begin{array}{l}\text { Nonuniform hydride distribution with } \\
\text { higher concentrations near the cladding } \\
\text { outer surface }\end{array}$ \\
\hline $79-4840$ & 11,020 & 100 & 401 & $\begin{array}{l}\text { Nonuniform hydride distribution with } \\
\text { higher concentrations near the cladding } \\
\text { outer surface }\end{array}$ \\
\hline
\end{tabular}

* Defect hole 
Table VI (Continued)

\begin{tabular}{|c|c|c|c|c|}
\hline Rod & $\begin{array}{l}\text { Irradiation } \\
\text { Time (EFPH) }\end{array}$ & $\begin{array}{l}\text { Power } \\
\text { Level } \\
(\% \text { Peak) }\end{array}$ & $\begin{array}{l}\text { Measured Hy } \\
\text { Vacuum } \\
\text { Extraction }\end{array}$ & $\begin{array}{l}\text { en Content (ppm) } \\
\text { Metallography }\end{array}$ \\
\hline $79-5040$ & 12,080 & 100 & 292 & $\begin{array}{l}100-150 \mathrm{ppm} \text { in inner } 2 / 3 \text { of cladding, } \\
250-1000 \mathrm{ppm} \text { in outer } 1 / 3 \text { of cladding }\end{array}$ \\
\hline $79-5500$ & 1490 & 100 & 149 & $\begin{array}{l}100 \mathrm{ppm} \text { in inner } 3 / 4 \text { of cladding } \\
225 \mathrm{ppm} \text { in outer } 1 / 4 \text { of cladding }\end{array}$ \\
\hline $79-583 D$ & 4820 & 100 & 321 & $\begin{array}{l}100 \mathrm{ppm} \text { at inner surface, } \\
300-500 \mathrm{ppm} \text { at outer surface; } \\
100 \mathrm{ppm} \text { near defect hole }\end{array}$ \\
\hline $79-594 D$ & 5975 & 100 & 212 & $\begin{array}{l}75-100 \mathrm{ppm} \text { at inner surface, } \\
330-560 \mathrm{ppm} \text { at outer surface }\end{array}$ \\
\hline $79-5950$ & 1235 & 100 & 187 & $\begin{array}{l}\text { Nonuniform hydride distribution } \\
\text { with higher concentration near } \\
\text { the cladding outer surface }\end{array}$ \\
\hline 79-6090 & 19,970 & $\begin{array}{l}100 \\
92^{\star}\end{array}$ & 351 & $\begin{array}{l}\text { Nonuniform hydride distribution } \\
\text { with higher concentration near } \\
\text { the cladding outer surface }\end{array}$ \\
\hline
\end{tabular}

* Defect hole 
Table VI (Cont'd)

\begin{tabular}{|c|c|c|c|c|}
\hline Rod & $\begin{array}{l}\text { Irradiation } \\
\text { Time (EFPH) }\end{array}$ & $\begin{array}{l}\text { Power } \\
\text { Level } \\
(\% \text { Peak })\end{array}$ & $\begin{array}{l}\text { Measured Hy } \\
\text { Vacuum } \\
\text { Extraction }\end{array}$ & $\begin{array}{l}\text { en Content (ppm) } \\
\text { Metallography }\end{array}$ \\
\hline \multicolumn{2}{|c|}{ 79-609D (Cont'd) } & $\begin{array}{c}90 \\
50 \\
5 \\
0 \text { (bottom) } \\
0 \text { (top) } \\
0 \text { (plenum) }\end{array}$ & $\begin{array}{l}485 \\
135 \\
100 \\
\ldots-\ldots\end{array}$ & $\begin{array}{l}500 \mathrm{ppm} \\
400-600 \mathrm{pm} \\
20- \\
150 \mathrm{ppm} \text { uniformly distributed } \\
2000-16,300 \mathrm{ppm}\end{array}$ \\
\hline $79-6140$ & 5900 & $\begin{array}{r}100 \\
50\end{array}$ & $\begin{array}{l}174 \\
246\end{array}$ & $\begin{array}{l}50-150 \mathrm{ppm} \text { at inner surface, } \\
300-600 \mathrm{ppm} \text { at outer surface }\end{array}$ \\
\hline $81-840$ & 2545 & 100 & 89 & $100 \mathrm{ppm}$ \\
\hline $81-890$ & 2545 & 100 & 104 & 100 ppm \\
\hline
\end{tabular}


Table VII

Measured and CHORT-Calculated Cladding Inside Surface Peak Power Corrosion of Intentionally Defected LWBR Irradiation Test Rods

\begin{tabular}{|c|c|c|c|c|c|c|}
\hline Rod & $\begin{array}{l}\text { Zircaloy } \\
\text { Cladding } \\
\text { Condition }\end{array}$ & EFPH & $\begin{array}{l}\text { Peak Inside } \\
\text { Cladding } \\
\text { Temperature } \\
\left({ }^{\circ} \mathrm{F}\right)\end{array}$ & $\begin{array}{r}\text { Interr } \\
\text { Measured }\end{array}$ & $\begin{array}{l}\text { ide Thickness (mil } \\
\text { CHORT-Calculated }\end{array}$ & $R^{\star}$ \\
\hline $81-84 D$ & RXA & 2,545 & 611 & 0.17 & 0.11 & 0.65 \\
\hline $81-890$ & SRA & 2,545 & 612 & 0.18 & 0.12 & 0.67 \\
\hline $79-5950$ & RXA & 1,235 & 736 & 0.50 & 0.30 & 0.60 \\
\hline $79-4430$ & RXA & 3,690 & 780 & 1.00 & 0.81 & 0.81 \\
\hline $79-6140$ & $R X A$ & 5,900 & 698 & 0.80 & 0.97 & 1.21 \\
\hline $79-5940$ & $R \times A$ & 5,975 & 718 & 1.04 & 1.07 & 1.03 \\
\hline $79-5040$ & SRA & 12,080 & 712 & 1.04 & 1.10 & 1.06 \\
\hline $79-6090$ & RXA & 19,970 & 697 & 2.00 & 2.18 & 1.09 \\
\hline
\end{tabular}

$\star R=$ Calculated Oxide Thickness

Measured Average 
Table VIII

Measured and CHORT-Calculated Hyriding of Intentionally Defected LWBR Irradiation Test Rods

\begin{tabular}{|c|c|c|c|c|c|c|}
\hline Rod & EFPH & $\begin{array}{l}\text { Measured } \\
\text { Internal } \\
\text { Oxide (mils) }\end{array}$ & $\begin{array}{c}\text { Power } \\
\text { Level } \\
(\% \text { Peak) }\end{array}$ & $\begin{array}{l}\text { Total Hydrogen } \\
\text { CHORT- } \\
\text { Calculated }\end{array}$ & $\begin{array}{c}\text { Content (ppm) } \\
\text { Vacuum } \\
\text { Extraction }\end{array}$ & $\mathrm{R}$ * \\
\hline $81-84 D$ & 2,545 & 0.17 & 100 & 82 & 89 & 0.92 \\
\hline $81-890$ & 2,545 & 0.18 & 100 & 88 & 104 & 0.85 \\
\hline $79-595 D$ & 1,235 & 0.50 & 100 & 146 & 187 & 0.78 \\
\hline $79-4430$ & 3,690 & 1.00 & $\begin{array}{r}100 \\
93 \\
90\end{array}$ & $\begin{array}{l}375 \\
345 \\
315\end{array}$ & $\begin{array}{l}365 \\
505 \\
403\end{array}$ & $\begin{array}{l}1.03 \\
0.68 \\
0.78\end{array}$ \\
\hline $79-6140$ & 5,900 & 0.80 & 100 & 395 & 174 & 2.27 \\
\hline $79-5940$ & 5,975 & 1.04 & 100 & 405 & 212 & 1.91 \\
\hline 79-504D & 12,080 & 1.04 & 100 & 465 & 292 & 1.59 \\
\hline $79-6090$ & 19,970 & 2.00 & $\begin{array}{c}100 \\
90 \\
5\end{array}$ & $\begin{array}{l}863 \\
753 \\
83\end{array}$ & $\begin{array}{l}351 \\
485 \\
735\end{array}$ & $\begin{array}{l}2.52 \\
1.55 \\
0.14\end{array}$ \\
\hline
\end{tabular}


WA'PD'TM-1393

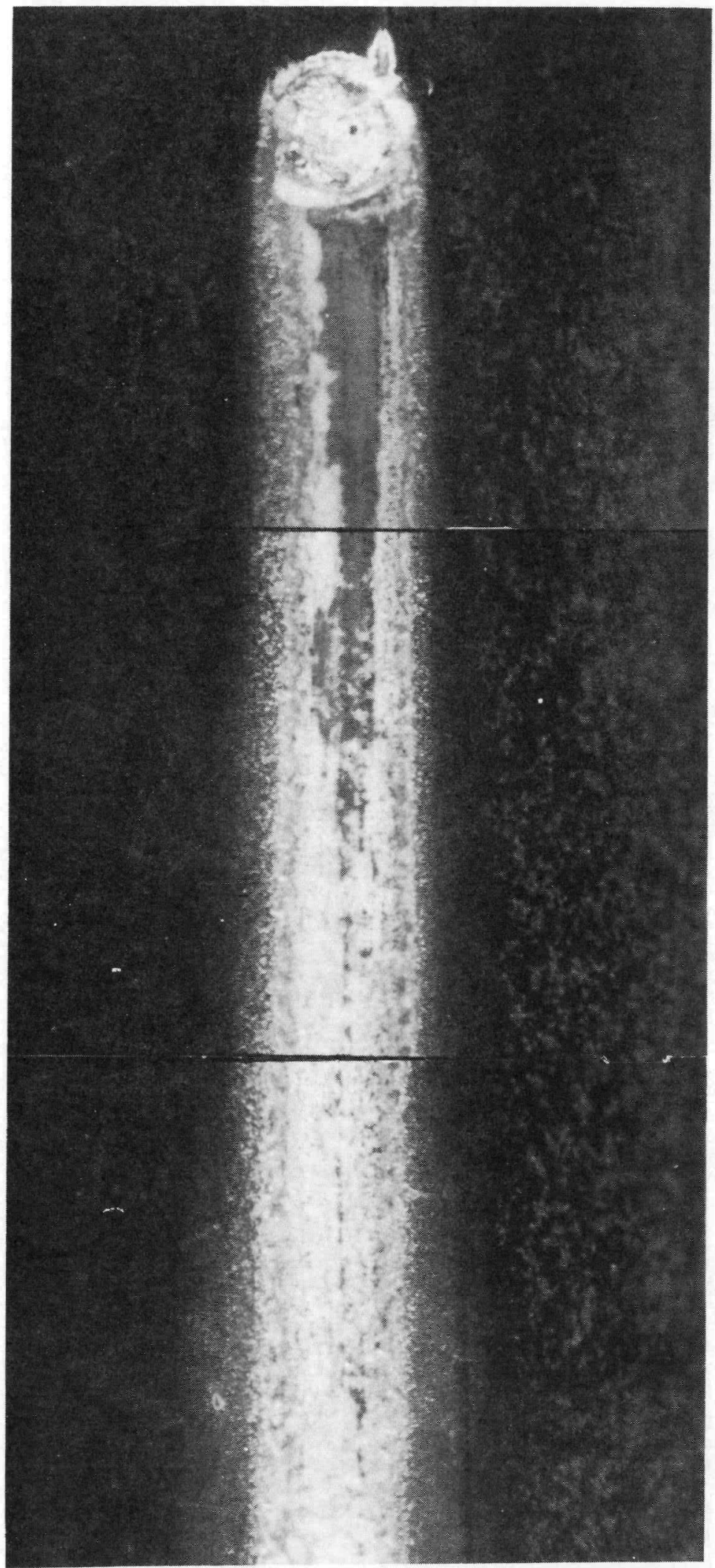

FIGURE 1

GRIP IIIB Rod 79-609D Defect Hole Streamer At Test Termination $(19,970 \mathrm{EFPH})(\mathrm{X} 18.1)$ 
Outer Cladding

Surface
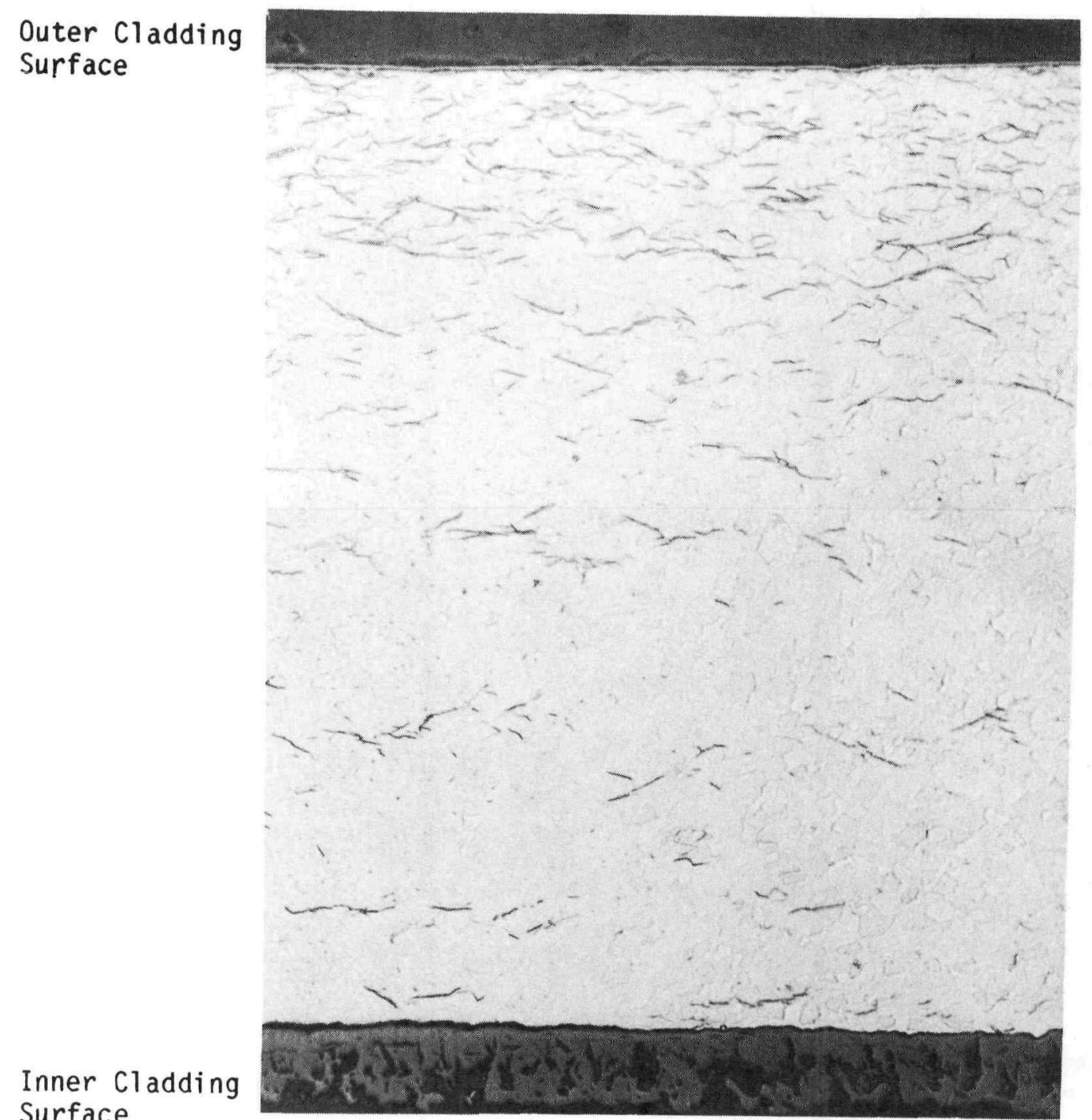

(a) 200 ppm hydrogen

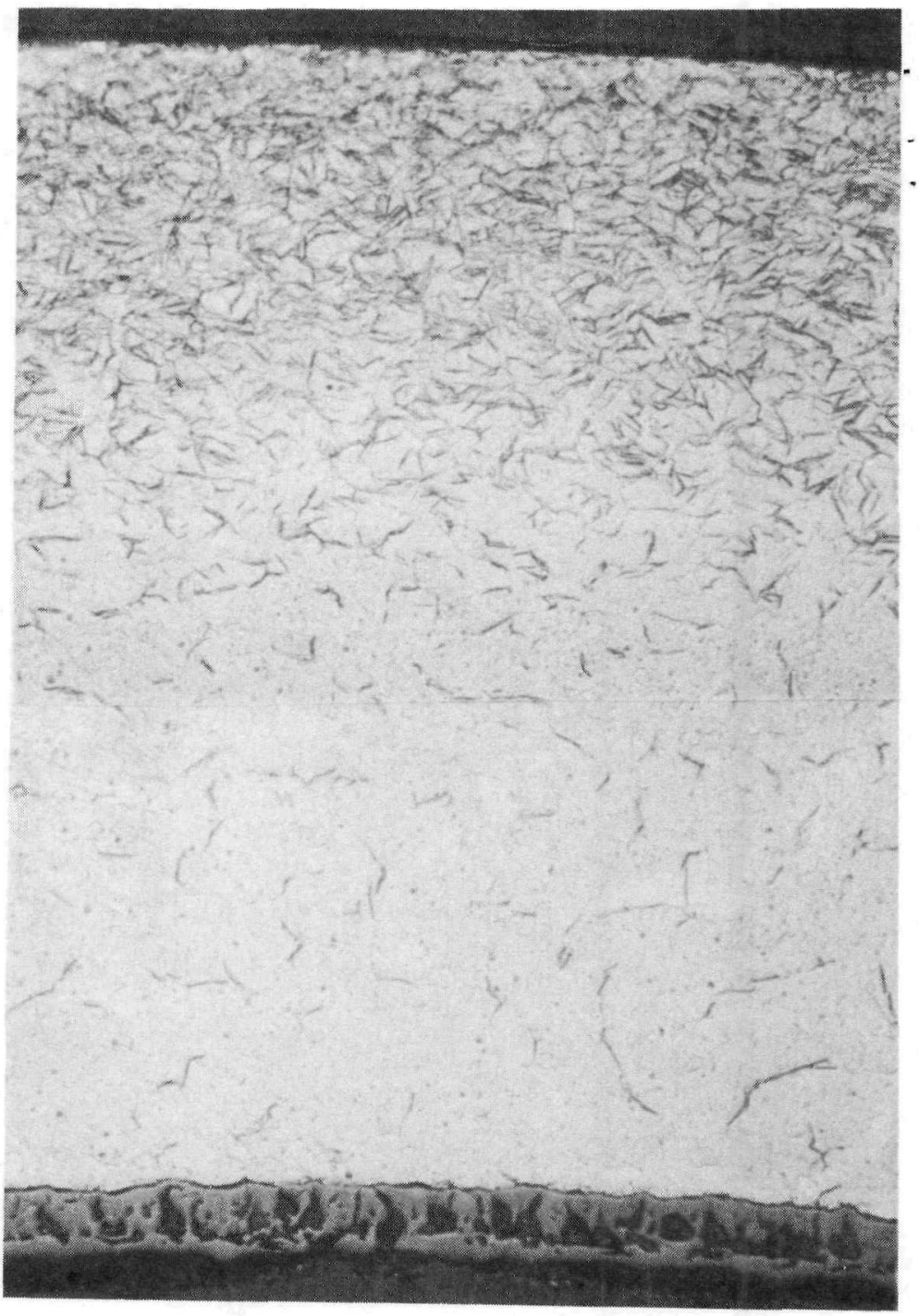

(b) 1000 ppm hydrogen

FIGURE 2

Hydrogen Gradients in GRIP IIIB Rod 79-609D (X250)

$-39-$ 


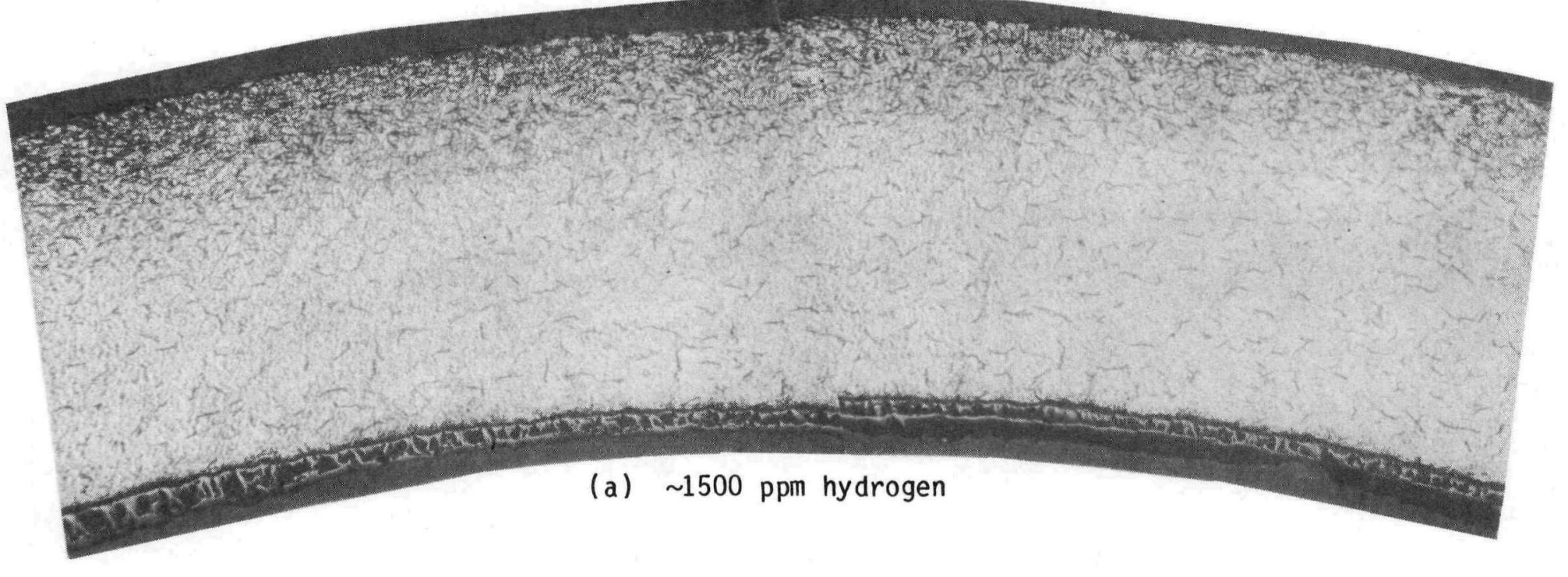

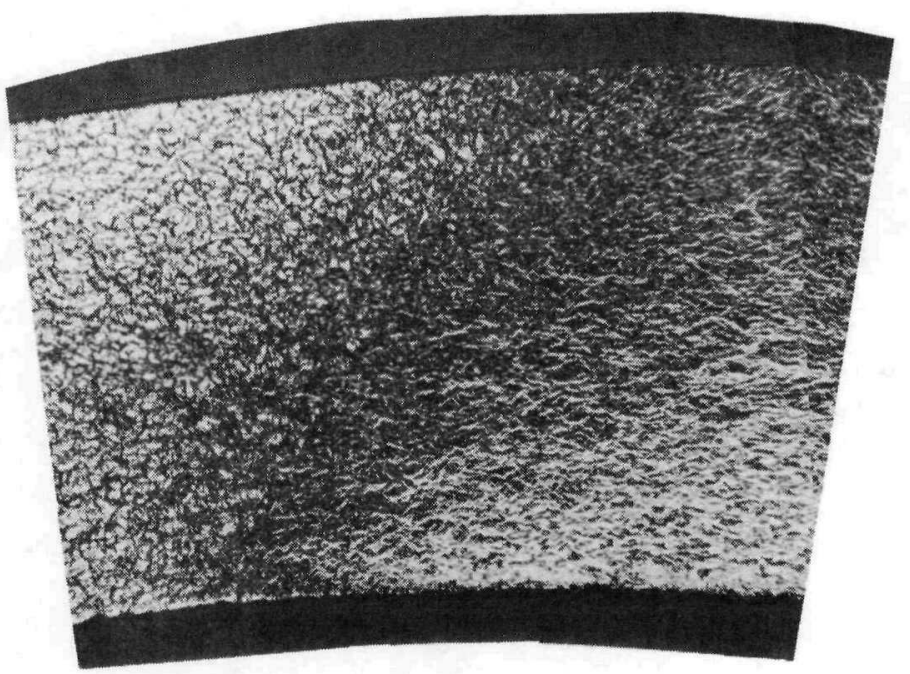

(b) $\sim 5000-\sim 12,000$ ppm hydrogen

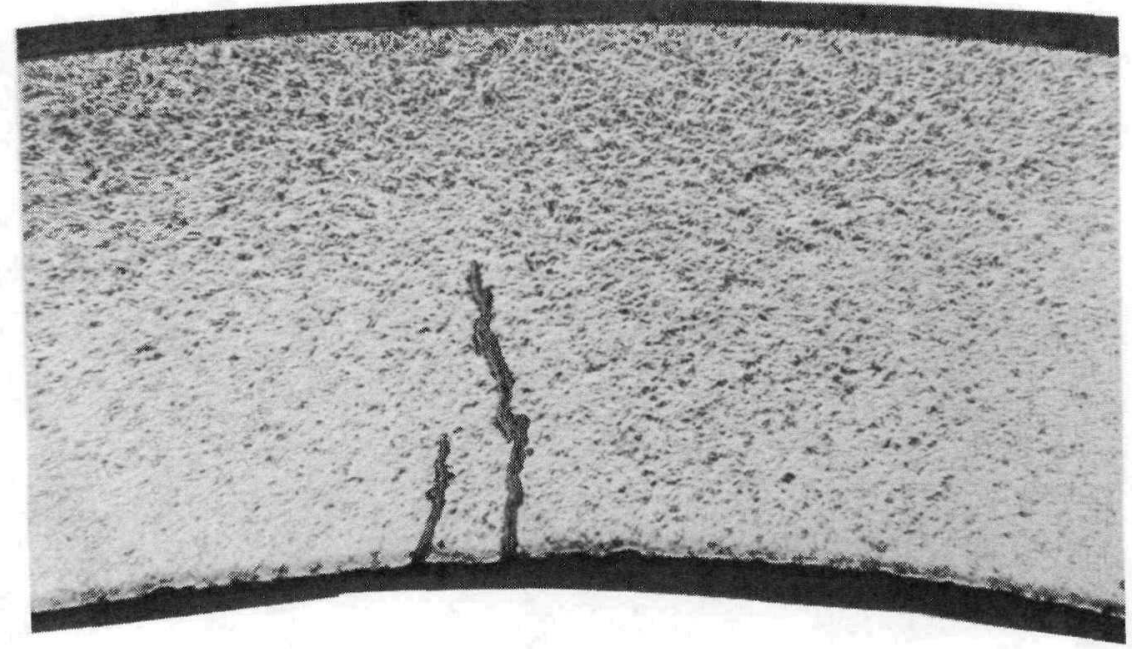

(c) $16,300 \mathrm{ppm}$ hydrogen

FIGURE 3

Accelerated and Massive Hydriding in GRIP IIIB ROD 70-609D (X100) 
RXA ZIRCALOY CORROSION: REGRESSION OF MEASURED VERSUS CHORT-CALCULATED OUTSIDE OXIDE THICKNESS

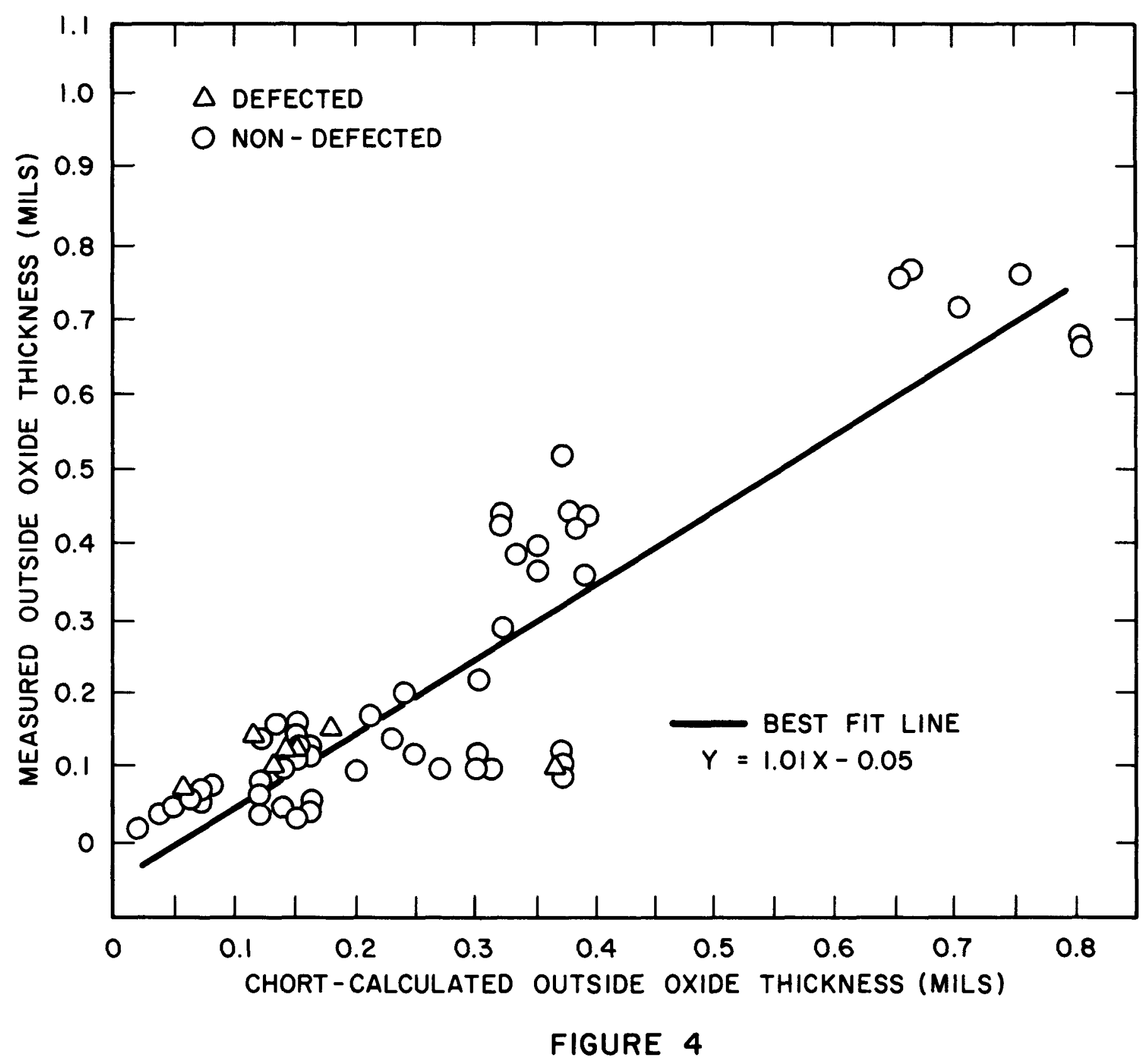


SRA ZIRCALOY-4 CORROSION: REGRESSION OF MEASURED VERSUS CHORT-CALCULATED OUTSIDE OXIDE THICKNESS

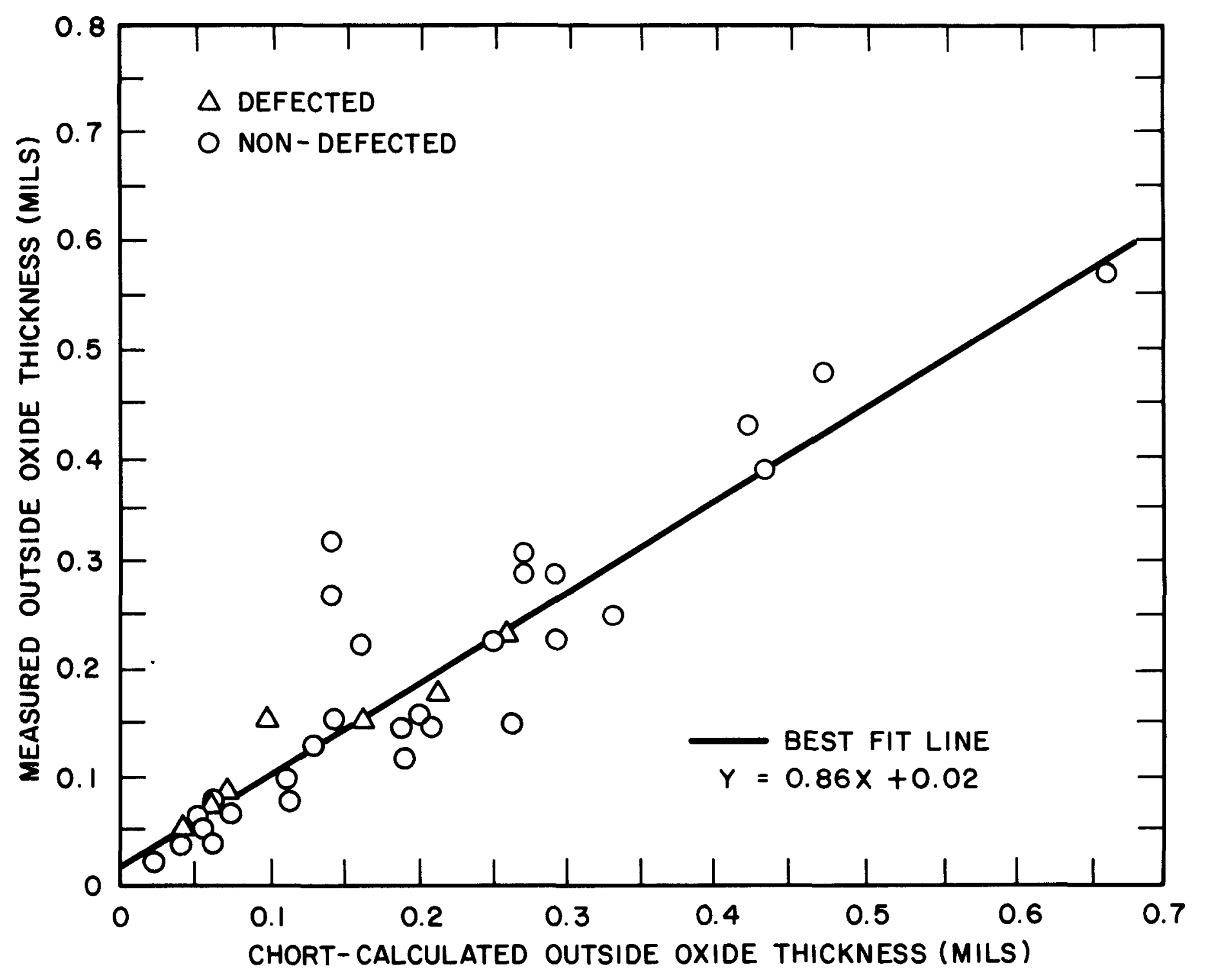

FIGURE 5 

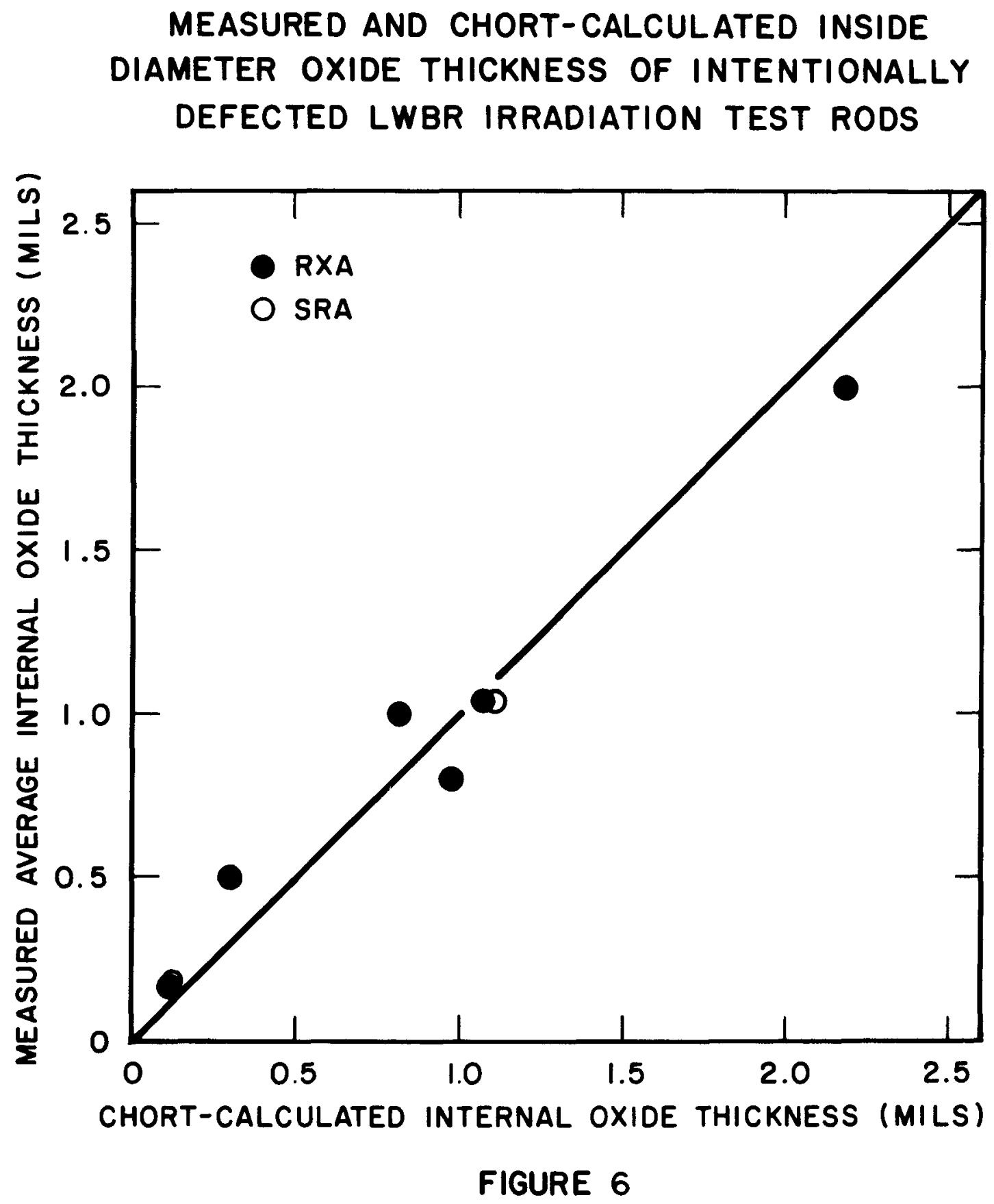


\section{APPENDIX A}

\section{CHORT PROGRAM FORMULATION}

CHORT is based on the assumption that cyclic transitions gccur at constant corrosion product weight gains $\left(W_{T R}\right)$ equal to $27.53 \mathrm{mg} / \mathrm{dm}^{2}$ for SRA Zircaloy and $31.00 \mathrm{mg} / \mathrm{dm}^{2}$ for RXA material. After each transition, corrosion kinetics of the initial cycle are repeated. The computer is programmed to solve the generalized corrosion equation:

$$
W=[A \exp (-Q / T) t]^{1 / 3}+R \phi_{f} t+K \dot{f} t,
$$

where

$W=$ corrosion product weight gain,

$A=$ fitting constant for thermal corrosion in water or steam, input variable, constant for a given environment,

$Q=$ activation constant for thermal corrosion in water or steam, input variable, constant for a given environment,

$T=$ Zircaloy cladding surface temperature, input variable,

$t=$ exposure time, input variable,

$R=$ proportionality constant for irradiation-induced corrosion,

$\phi_{f}=$ fast neutron flux, input variable,

$K=$ proportionality constant for inside surface fission-induced corrosion, and

$\dot{f}=$ volumetric fissioning rate, input variable.

Values of the input constants are listed in Table A-1.

The first term of Equation (A-1) represents the thermal corrosion contribution to the oxide weight gain. Since the kinetics of the corrosion oxidation reaction are affected by the phase change of water to steam, both phase regions are modeled in CHORT. Steam kinetics are assumed to govern at temperatures greater than $750^{\circ} \mathrm{F}$. Steam kinetics were added to provide a representation of high temperature corrosion in the CHORT model. 
The second term of Equation $(A-1)$ is the corrosion contribution due to radiation enhancement. The value of $R$ used in CHORT is based upon in-pile test data (Reference 5).

The third term of Equation $(A-1)$ is the corrosion contribution due to inside surface fissioning enhancement and is included for defected rod corrosion calculations.

CHORT solves Equation (A-1) for any given time step, $\Delta t$. Time intervals between each solution of Equation (A-1) are input variables. After each weight gain calculation, the calculated value is compared to the experimentally determined limit value, $W_{T R}$ (the weight gain at transition), and the calculations are repeated; i.e., once the total weight gain reaches the transition value specified in the input, the equation is iterated for another cycle. Weight gains are additive over the chosen time period for corrosion exposure. When graphed as weight gain versus time, the resulting solution appears as a series of pre-transition steps of equal height.

Table A-I

CHORT Input Constants for Zircaloy

$\begin{array}{lcc}\text { Constant } & \frac{\text { Water }}{A} & \frac{\text { Steam }}{1.164 \times 10^{13}} \\ Q\left(\mathrm{cal} /{ }^{\circ} \mathrm{K} / \mathrm{mole}\right) & 6.357 \times 10^{11} & 1.5590 \times 10^{4} \\ \text { SRA WTR }\left(\mathrm{mg} / \mathrm{dm}^{2}\right) & 1.3636 \times 10^{4} & 27.53 \\ \text { RXA WTR }\left(\mathrm{mg} / \mathrm{dm}^{2}\right) & 27.53 & 31.00 \\ R(\mathrm{mg} / 100 \text { neutrons }) & 31.00 & 0.752 \times 10^{-20} \\ \mathrm{~K}(\mathrm{mg}-\mathrm{cm} / 100 \text { fissions }) & 2.04 \times 10^{-19} & 2.04 \times 10^{-19}\end{array}$


The objectives of the LWBR irradiation test program were to test fuel rods under heat fluxes, fast neutron fluxes, and fuel depletions expected in the LWBR core (Section 2A), to confirm satisfactory performance for design lifetime, and to support development of performance analyses for LWBR fuel rods. The program for measuring corrosion and hydriding in Zircaloy -4 cladding of defected fuel rods consisted of rods from the 14 tests summarized in Table B-I. These irradiation tests were performed in the Engineering Test Reactor (ETR) and the Advanced Test Reactor (ATR) at the Idaho National Engineering Laboratory and in the National Research Experimental Reactor (NRX) located at Chalk River, Ontario, Canada, which is owned and operated by the Atomic Energy of Canada Limited.

Nineteen fuel rods (14 seed and 5 blanket) were intentionally defected with drilled holes prior to testing. A larger ( 35 mil diameter) spotting hole was first drilled halfway through the cladding wall from the outside surface and then continued through the wall to the inside surface with a smaller $(\sim 5 \mathrm{mil}$ diameter) defect hole. The fuel stacks of some of the defected rods were short ( 6 to 11 inches in length). However, five seed rods and four blanket rods were of LWBR length, i.e., up to 118 inches long. Holes were located approximately halfway up the fuel stack on short rods and within 24 inches of the bottom on long rods, except on seed rod 79-4430 where the hole was located at the bottom endplug-pellet stack interface. 
TABLE B-I

LWBR Defected Irradiation Tests Containing Fuel Rods Examined for Cladding Corrosion and Hydriding

\begin{tabular}{|c|c|c|c|c|}
\hline Designation & Test Name & $\begin{array}{l}\text { Rod } \\
\text { Type }\end{array}$ & $\begin{array}{l}\text { Heat } \\
\text { Treatment } \\
\text { Cladding } \\
\end{array}$ & $\begin{array}{l}\text { Test } \\
\text { Reactor } \\
\end{array}$ \\
\hline$M-13-S 2$ & Seed Rod Screening & Seed & RXA & ETR \\
\hline$M-13-53$ & Seed Rod Screening & Seed & RXA & ETR \\
\hline$M-13-S 3 A$ & Seed Rod Screening & Seed & $\mathrm{RXA}$ & ETR \\
\hline$M-13-S 4$ & Seed Rod Screening & Seed & RXA & ETR \\
\hline GRIP II & Grid Rod In-Pile & Seed & RXA & ETR \\
\hline GRIP IIIA & Grid Rod In -Pile & Seed & RXA & ETR \\
\hline GRIP IIIB & Grid Rod In-Pile & Seed & $\mathrm{RXA}$ & ATR \\
\hline LSR & Long Seed Rod & Seed & $\mathrm{RXA}$ & NRX \\
\hline$\cdots$ & Production Thoria & Seed & RXA, SRA & ETR \\
\hline$C-7 B 3$ & $\begin{array}{l}\text { Blanket Screening } \\
\text { Test }\end{array}$ & Blanket & SRA & ETR \\
\hline$C 7-B 3 A$ & $\begin{array}{l}\text { Blanket 6-Rod } \\
\text { Assembly }\end{array}$ & Blanket & SRA & ETR \\
\hline C7-BBT & Blanket Bundle Test & Bl anket & SRA & ETR \\
\hline SBR & Short Blanket Rod & Blanket & SRA & NRX \\
\hline NLBR & $\begin{array}{l}\text { New Long Blanket } \\
\text { Rod }\end{array}$ & Blanket & SRA & NRX \\
\hline
\end{tabular}




\section{APPENDIX C}

\section{HYDIZ ANALYSES}

1. Objective

Hydrogen diffusion and distribution in the Zircaloy cladding of

intentionally defected GRIP IIIB rod 79-6090 with high irradiation time $(19,970 \mathrm{EFPH})$ and fluence $\left(101 \times 10^{20} \mathrm{n} / \mathrm{cm}^{2}\right)$ were analyzed with the HYDIZ (Hydrogen Distribution in Zircaloy) thermal gradient model (Reference 15) and compared with experimental measurements. The purpose was to determine if the axial distribution of hydrogen could be explained by the axial temperature distribution.

II. HYDIZ Calculations

The power and metallographic examination positions for Rod 79-6090 are illustrated in Figure $\mathrm{C}-1$ and its hydride distributions are listed in Table VI. Hydride distributions for other defected test rods are also given in Table VI. In general, the metallographic examinations showed heavier hydride concentrations at the outer surfaces of the cladding of the irradiated test rods and greater hydrogen contents away from the defect hole and peak power positions.

The inside cladding temperatures were calculated with the FIGRO (Fission Irradiation Growth) analys is procedure, Reference (13). FIGRO caTculated temperatures and measured and estimated hydride contents were used as input data for initial one-dimensional annealing analyses with the HYDIZ program. Radial hydrogen distributions for various initially uniform hydrogen concentrations (83-863 ppm), obtained from Table VIII, were calculated for $5 \%, 90 \%$ and peak power locations with temperature gradients of $2100-4900^{\circ} \mathrm{F} / \mathrm{in}$. The results listed in Table C-I are in qualitative agreement with the experimental metallographic data of Table VI, i.e., hydrogen diffuses radially due to the steep temperature gradients and concentrates at the cooler outside cladding surfaces in relatively short time periods (25-50 hrs). Thus, the HYD1Z calculation provides results that are at least in qualitative agreement with observed through clad thickness hydrogen distribution.

A one-dimensional approximation for hydrogen redistribution and pickup over both surfaces of a 30-inch axial segment, representing peak and $5 \%$ power positions, was calculated with the equation

$C_{H}=J_{C} \exp (Q / T) t$,

where

$C_{H}=$ hydrogen concentration in $\mathrm{g} / \mathrm{cm}^{2}$,

$J_{c}=$ hydrogen ingress rate in $\mathrm{g} / \mathrm{cm}^{2} / \mathrm{sec}$, 


$$
\begin{aligned}
& Q=\text { corrosion activitation energy in cal } /^{\circ} \mathrm{K} / \mathrm{mole}, \\
& T=\text { reaction temperature in }{ }^{\circ} \mathrm{K}, \\
& t=\text { corrosion/hydriding temperature in days. }
\end{aligned}
$$

The initial hydrogen concentration was $12 \mathrm{ppm}$, and hydrogen ingress rates were designed to yield end of life average hydrogen concentrations of $\sim 500$ - $700 \mathrm{ppm}$. The results given in Table C-II were as would be expected for a constant hydrogen ingress rate, i.e., greater hydrogen absorption at the higher temperature peak power region. Little, if any, axial diffusion of hydrogen in the Zircaloy cladding is indicated because hydrogen concentration is calculated to increase with increasing temperature and negligible hydrogen redistribution has occurred. In fact, greater hydrogen concentrations are calculated at the hot (peak power) region for the higher maximum temperature case.

Axial hydrogen redistributions from peak power to $90 \%$ and to $5 \%$ power positions were calculated as a function of temperature gradients. FIGRO calculated temperatures of $697^{\circ}$ and $687^{\circ} \mathrm{F}$ for the peak and $90 \%$ power positions as well as a minimum temperature of $510^{\circ} \mathrm{F}$ for the $5 \%$ power position were used as input. The calculated redistributions are presented in Table C-III. In case 1, a one-dimensional approximation for hydrogen redistribution was calculated over a 30 -inch axial segment at peak $\left(697^{\circ} \mathrm{F}\right)$ and $5 \%\left(510^{\circ} \mathrm{F}\right)$ power positions. The resulting temperature gradient was $\sim 6^{\circ} \mathrm{F} /$ in and very little axial hydrogen diffusion was indicated. In cases 2 and 3 , hydrogen redistributions were calculated for two- and one-inch axial segments at peak $\left(697^{\circ} \mathrm{F}\right)$ and $90 \%\left(687^{\circ} \mathrm{F}\right)$ power positions. The temperature gradients were $\leq 10^{\circ} \mathrm{F} /$ in and, again, little axial hydrogen migration was shown. In cas̄es 4 and 5 , the temperature gradients were increased by an order of magnitude and axial hydrogen redistribution was calculated to have occurred. Thus, only for temperature gradients much steeper than those existing axially in the defected LWBR test rods, estimated to be $<10^{\circ} \mathrm{F} / \mathrm{in}$, is the hydrogen predicted to diffuse significantly in the axial direction towards the cooler low power regions.

\section{Conclusions}

Diffusion of hydrogen due to the axial thermal gradients in fuel rods was calculated. Very little hydrogen migration in the axial direction is calculated to have occurred. This indicates that the driving forces of concentration and temperature gradient are calculationally insufficient to account for the increased hydrogen concentrations at the lower power locations observed in defected GRIP III B rod 79-609D. 
GRIP - IIIB ROD 79-609D

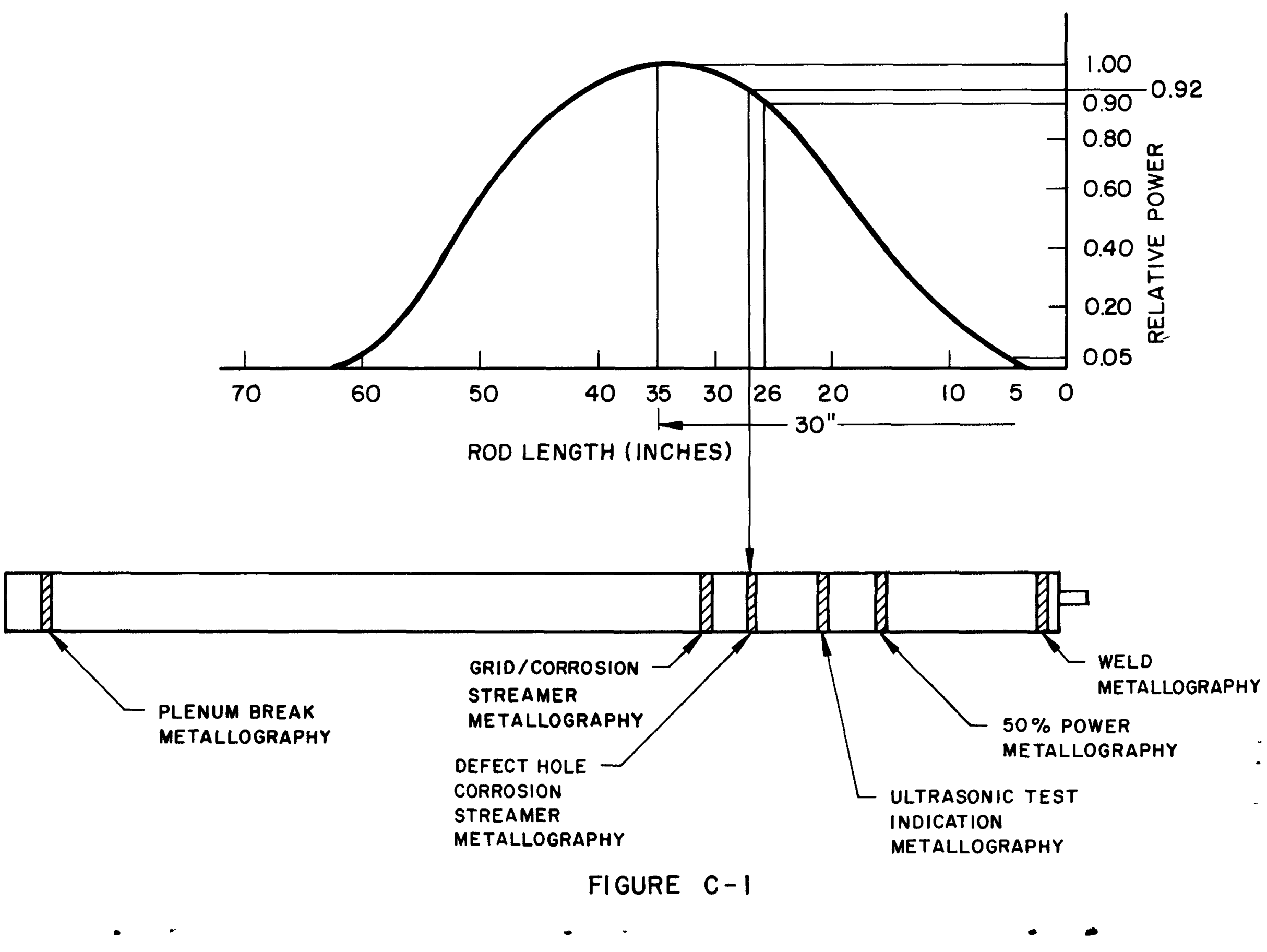

PLENUM BREAK METALLOGRAPHY 
TABLE C-I

Calculated Radial Hydrogen Diffusion in Rod 79-609D

Input Data to HYDIZ

\begin{tabular}{|c|c|c|c|c|}
\hline Case 1 & Case 2 & Case 3 & Case 4 & Case 5 \\
\hline $\begin{array}{l}863 \\
697 \\
595\end{array}$ & $\begin{array}{l}351 \\
697 \\
595\end{array}$ & $\begin{array}{l}735 \\
688 \\
589\end{array}$ & $\begin{array}{l}485 \\
688 \\
589\end{array}$ & $\begin{array}{c}83 \\
610 \\
566\end{array}$ \\
\hline
\end{tabular}

Clad I.D. temperature $\left({ }^{\circ} \mathrm{F}\right) \quad 697$

$\mathrm{Clad} 0 . \mathrm{D}$. temperature $\left({ }^{\circ} \mathrm{F}\right)$

$\underset{(\mathrm{ppm})}{\mathrm{H}_{2}}$

$\begin{array}{r}\mathrm{H}_{2} \\ (\mathrm{ppm}) \\ \hline\end{array}$

$\begin{array}{r}\mathrm{H}_{2} \\ (\mathrm{ppm}) \\ \hline\end{array}$

$\begin{array}{r}\mathrm{H}_{2} \\ (\mathrm{ppm}) \\ \hline\end{array}$

$\underline{\mathrm{Hpm}_{2}}$

1. (I.D. Surface)

113

2.

3.

117

122

185

875

887

943

1112

1402

1647

93

96

100

105

109

119

362

392

493

707

1810

1153

107

112

116

201

744

755

798

936

1173

1377

1514

98
102
106
110
318
496
513
585
745
967
1337

11. (0.D. Surface)

1337

102

*0.02075 inch: cladding thickness

+ initially uniform 


\section{TABLE C-II}

Calculated Hydrogen Pickup and Axial Migration in Rod 79-609D

Input Data to HYDIZ

Initial hydrogen concentration (ppm)

Clad length (in)

Clad thickness (in)

Hot end peak power temperature $\left({ }^{\circ} \mathrm{F}\right)$

Cold end $5 \%$ power temperature $\left({ }^{\circ} \mathrm{F}\right)$

Hydrogen ingress rate $\left(\mathrm{g} / \mathrm{cm}^{2} / \mathrm{sec}\right)$ coefficient

Corrosion activation energy $\left(\mathrm{cal} /{ }^{\circ} \mathrm{K} / \mathrm{mole}\right.$ Corrosion/Hydriding time (days)

Axial Zone

1 (5\% power, cold end)

2

3

4

5

6

7

8

9

10

11

12

13

14

15

16

17 (100\% power, maximum temperature)

Average hydrogen concentration (ppm) at end of life
Case 1 12

30

0.5

646

538

$2.39 \times 10^{-2}$

$-12,529$

832.68

$\mathrm{H}_{2}$ (ppm)

157

162

183

210

240

276

316

361

413

472

538

613

697

791

897

1013

1104

488
Case 2

12

30

0.5

697

510

$2.39 \times 10^{-2}$

$-12,529$

729.8

$\underline{\mathrm{H}_{2}}$ (ppm)

91

95

116

145

183

232

292

368

461

576

717

890

1100

1354

1660

2023

2357

709 
TABLE C-III

Calculated Hydrogen Redistribution in Axial Segments of Rod 79-6090

\begin{tabular}{|c|c|c|c|c|c|}
\hline Input Data to HYDIZ & Case 1 & Case 2 & Case 3 & Case 4 & Case 5 \\
\hline $\begin{array}{l}\text { Hydrogen concentration (ppm) } \\
\text { Clad length (in) } \\
\text { Clad thickness (in) } \\
\text { Maximum temperature }\left({ }^{\circ} \mathrm{F}\right) \\
\text { Minimum temperature }\left({ }^{\circ} \mathrm{F}\right) \\
\text { Temperature gradient }\left({ }^{\circ} \mathrm{F} / \mathrm{in}\right)\end{array}$ & $\begin{array}{l}900 \\
30 \\
0.5 \\
697 \\
510 \\
6.2\end{array}$ & $\begin{array}{r}754 \\
2 \\
0.02 \\
697 \\
687 \\
5\end{array}$ & $\begin{array}{r}754 \\
1 \\
0.02 \\
697 \\
687 \\
10\end{array}$ & $\begin{array}{l}754 \\
2 \\
0.02 \\
697 \\
510 \\
93.5\end{array}$ & $\begin{array}{r}754 \\
1 \\
0.02 \\
697 \\
510 \\
187\end{array}$ \\
\hline Axial Zone & $\begin{array}{l}\mathrm{H}_{2} \\
\text { (ppm) }\end{array}$ & $\begin{array}{l}\mathrm{H}_{2} \\
\text { (ppm) }\end{array}$ & $\begin{array}{l}\mathrm{H}_{2} \\
\text { (ppm) }\end{array}$ & $\begin{array}{l}\mathrm{H}_{2} \\
\text { (ppm) }\end{array}$ & $\begin{array}{l}\mathrm{H}_{2} \\
\text { (ppm) }\end{array}$ \\
\hline $\begin{array}{l}1 \text { (peak power, peak temperature) } \\
2 \\
3 \\
4 \\
5 \\
6 \\
7 \\
8 \\
9 \\
10 \\
11\end{array}$ & $\begin{array}{l}900 \\
907 \\
911 \\
911 \\
909 \\
907 \\
906 \\
906 \\
914\end{array}$ & $\begin{array}{l}754 \\
755 \\
755 \\
756 \\
756 \\
757 \\
758 \\
759 \\
760 \\
761 \\
762\end{array}$ & $\begin{array}{l}754 \\
757 \\
760 \\
763 \\
766 \\
768\end{array}$ & $\begin{array}{l}138 \\
758 \\
772 \\
782 \\
789 \\
792 \\
791 \\
803 \\
803 \\
806 \\
1016\end{array}$ & $\begin{array}{l}93 \\
107 \\
768 \\
788 \\
1148 \\
1986\end{array}$ \\
\hline
\end{tabular}


APPENDIX D

LIST OF ABBREVIATIONS AND ACRONYMS

ATR

AWBA

BA

BBT

CHORT

DOE

EFPH

ETR

FIGRO

GRIP

HYDIZ

LSR

LWBR

NLBR

NRX

RXA

SBR

SRA
Advanced Test Reactor

Advanced Water Breeder Applications

Blanket Assembly

Blanket Bundle Test

Corrosion and Hydriding of Reactor Tubing

Department of Energy

Effective Full Power Hours

Engineering Test Reactor

Fission Irradiation Growth

Grid Rod In-Pile

Hydrogen Distribution in Zircaloy

Long Seed Rod

Light Water Breeder Reactor

New Long Blanket Rod

National Research Experimental Reactor

Recrystallization Annealed

Short Blanket Rod

Stress-Relief Annealed 